\title{
EFFECTS OF LWR ENVIRONMENTS ON FATIGUE LIFE OF CARBON AND LOW-ALLOY STEELS*
}

\author{
O. K. Chopra and W. J. Shack \\ Energy Technology Division \\ Argonne National Laboratory \\ Argonne, IL 60439
}

\section{March 1995}

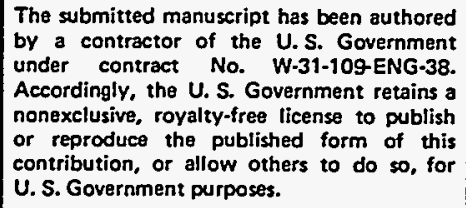

U.S. Government purposes.

\section{DISCLAIMER}

\begin{abstract}
This report was prepared as an account of work sponsored by an agency of the United States Government. Neither the United States Government nor any agency thereof, nor any of their employees, makes any warranty, express or implied, or assumes any legal liability or responsibility for the accuracy, completeness, or usefulness of any information, apparatus, product, or process disclosed, or represents that its use would not infringe privately owned rights. Reference herein to any specific commercial product, process, or service by trade name, trademark, manufacturer, or otherwise does not necessarily constitute or imply its endorsement, recommendation, or favoring by the United States Government or any agency thereof. The views and opinions of authors expressed herein do not necessarily state or reflect those of the United States Government or any agency thereof.
\end{abstract}

For presentation at the 1995 ASME/JSME Pressure Vessels and Piping Conference, July 23-27, 1995, Honolulu, HI.

*Work was supported by the Office of Nuclear Regulatory Research, U.S. Nuclear Regulatory Commission, under FIN Number A2212. 


\section{DISCLAIMER}

Portions of this document may be illegible in electronic image products. Images are produced from the best available original document. 


\title{
EFFECTS OF LWR ENVIRONMENTS ON FATIGUE LIFE OF CARBON AND LOW-ALLOY STEELS
}

\author{
Omesh K. Chopra and William J. Shack \\ Energy Technology Division \\ Argonne National Laboratory \\ Argonne, Illinois
}

\begin{abstract}
The ASME Boiler and Pressure Vessel Code provides rules for the construction of nuclear power plant components. Figure I-90 of Appendix I to Section III of the Code specifies fatigue design curves for structural materials. While effects of reactor coolant environments are not explicitly addressed by the design curves, test data suggest that the Code fatigue curves may not always be adequate in coolant environments. This paper reports the results of recent fatigue tests that examine the effects of steel type, strain rate, dissolved oxygen level, strain range, loading waveform, and surface morphology on the fatigue life of A 106-Gr B carbon steel and A533-Gr B low-alloy steel in water.
\end{abstract}

\section{INTRODUCTION}

The ASME Boiler and Pressure Vessel Code Section III, Division 1, Subsection NB, includes rules for the construction of Class 1 components in nuclear power plants. It recognizes fatigue as a possible mode of failure in pressure vessel steels and piping materials. The current Code design curves, specified in Figure I-90 of Appendix I to Section III, are based primarily on strain-controlled fatigue tests of small polished specimens in air at room temperature (1). The Code design curves were obtained by decreasing the best-fit curves to the experimental data by a factor of 2 on stress or a factor of 20 on cycles, whichever was more conservative at each point. The factors were intended to account for uncertainties in translating the experimental data of laboratory test specimens to actual reactor components. The factor of 20 on cycles is the product of three subfactors: 2 for scatter of data (minimum to mean), 2.5 for size effects, and 4 for surface finish, etc. (2). The effects of the coolant environment are not explicitly addressed in the Code design curves. However, recent fatigue strain vs. life (S-N) data from the United States (3-10) and Japan (11-13) illustrate potentially significant effects of the light water reactor (LWR) environment on the fatigue resistance of carbon and low-alloy steels. Specimen lives in simulated LWR environments can be much shorter than for the corresponding tests in air. These results raise the issue of whether the fatigue design curves in Section III are appropriate for the purposes intended and whether they adequately account for environmental effects on fatigue behavior.

Several key variables that influence environmental effects can be identified from the available $S-N$ data. The data indicate that water can have a significant effect on fatigue life only when all of the following four conditions are satisfied: sulfur content of the steel is $>0.003 \mathrm{wt} . \%$, temperature of the water is $\geq 150^{\circ} \mathrm{C}$, concentration of dissolved oxygen (DO) in the water is $\geq 0.05 \mathrm{ppm}$, and applied strain rate is $\leq 1 \% / \mathrm{s}$. Although these are the minimum conditions that must be met to produce significant degradation in fatigue life, the actual dependence of fatigue life on these variables involves complex synergistic interactions. When any one of the four threshold conditions is not satisfied, e.g., at very low DO levels characteristic of pressurized water reactors (PWRs) and boiling water reactors (BWRs) with hydrogen-water chemistry or at temperatures $<150^{\circ} \mathrm{C}$, environmental effects on fatigue life are modest. Based on the existing fatigue S-N data, Argonne National Laboratory (ANL) has developed interim design fatigue curves that explicitly address environmental effects on fatigue life of carbon and low-alloy steels (14).

This paper presents the results from fatigue tests conducted on A106-Gr B carbon steel and A533-Gr B low-alloy steel under conditions where information is lacking in the existing $\mathrm{S}-\mathrm{N}$ data base. The effects of various material and loading variables, e.g., steel type, strain rate, DO, strain range, loading waveform, and surface morphology, on fatigue life of carbon and lowalloy steels have been evaluated. A statistical model for estimat- 
Table 1. Chemical composition (wt.\%) of ferritic steels used for fatigue tests

\begin{tabular}{cllcccccccc}
\hline Material & Source & C & P & S & Si & Fe & Cr & Ni & Mn & Mo \\
\hline A.106-Gr B $^{2}$ & ANL & 0.29 & 0.013 & 0.015 & 0.25 & Bal & 0.19 & 0.09 & 0.88 & 0.05 \\
& Supplier & 0.29 & 0.016 & 0.015 & 0.24 & Bal & - & - & 0.93 & - \\
A533-Gr B b & ANL & 0.22 & 0.010 & 0.012 & 0.19 & Bal & 0.18 & 0.51 & 1.30 & 0.48 \\
& Supplier & 0.20 & 0.014 & 0.016 & 0.17 & Bal & 0.19 & 0.50 & 1.28 & 0.47 \\
\hline
\end{tabular}

${ }^{\mathrm{a}}$ Schedule 140 pipe $508-\mathrm{mm}$ O.D. fabricated by Cameron Iron Works, Heat J-7201. Actual heat treatment not known.

$b^{b}$ Hot-pressed plate $162 \mathrm{~mm}$ thick from Midland reactor lower head. Austenitized at $871-899^{\circ} \mathrm{C}$ for $5.5 \mathrm{~h}$ and brine quenched, then tempered at $649-663^{\circ} \mathrm{C}$ for $5.5 \mathrm{~h}$ and brine quenched. The plate was machined to a final thickness of $127 \mathrm{~mm}$. The I.D. surface was inlaid with $4.8-\mathrm{mm}$ weld cladding and stress relieved at $607^{\circ} \mathrm{C}$ for $23.8 \mathrm{~h}$.

Table 2. Average room-temperature tensile properties of the ferritic steels

\begin{tabular}{rcccc}
\hline & $\begin{array}{c}\text { Yield } \\
\text { Stress } \\
\text { Material }\end{array}$ & $\begin{array}{c}\text { Ultimate } \\
\text { Stress } \\
(\mathrm{MPa})\end{array}$ & $\begin{array}{c}\text { Elongation } \\
(\%)\end{array}$ & $\begin{array}{c}\text { Reduction } \\
\text { in Area } \\
(\%)\end{array}$ \\
\hline A106-Gr B & 301 & 572 & 23.5 & 44.0 \\
A533-Gr B & 431 & 602 & 27.8 & 66.6 \\
\hline
\end{tabular}

ing the effects of various material and loading conditions on fatigue life of ferritic steels is presented in a companion paper elsewhere in this proceedings.

\section{EXPERIMENTAL}

Low-cycle fatigue tests have been conducted on A106Gr B carbon steel and A533-Gr B low-alloy steel with MTS closed-loop electrohydraulic machines. The A533-Gr B material was obtained from the lower head of the Midland reactor vessel, which was scrapped before the plant was completed. The A106$\mathrm{Gr} \mathrm{B}$ material was obtained from a 508 -mm-diameter schedule 140 pipe fabricated by the Cameron Iron Works, Houston, TX. The chemical compositions of the two materials are given in Table 1, and average room-temperature tensile properties provided by the material suppliers are given in Table 2. Microstructures of the steels are shown in Fig. 1; carbon steel has a pearlitic structure, whereas the low-alloy steel consists of tempered bainite. Smooth cylindrical specimens with $9.5-\mathrm{mm}$ diameter and 19-mm gage length were used for the fatigue tests. Specimen gage length was given a $1-\mu \mathrm{m}$ surface finish in the axial direction to prevent circumferential scratches that might act as sites for crack initiation.

Tests in water were conducted in a small autoclave with an annular volume of $12 \mathrm{~mL}$. A schematic representation of the system is shown in Fig. 2. The once-through system consists of a 132-L supply tank, Pulsafeeder ${ }^{\mathrm{TM}}$ pump, heat exchanger, preheater, and the autoclave. Water is circulated at a rate of $\approx 10 \mathrm{~mL} / \mathrm{min}$ and a system pressure of $9 \mathrm{MPa}$. The autoclave is constructed of Type 316 SS and contains a titanium liner. The supply tank and most of the low-temperature piping are Type 304 SS; titanium tubing is used in the heat exchanger and for connections to the autoclave and the electrochemical potential (ECP) cell. The ECPs of platinum and an electrode constructed of the same material as the fatigue specimen were monitored during the test against an $0.1 \mathrm{M} \mathrm{KCl} / \mathrm{AgCl} / \mathrm{Ag}$ external reference electrode.

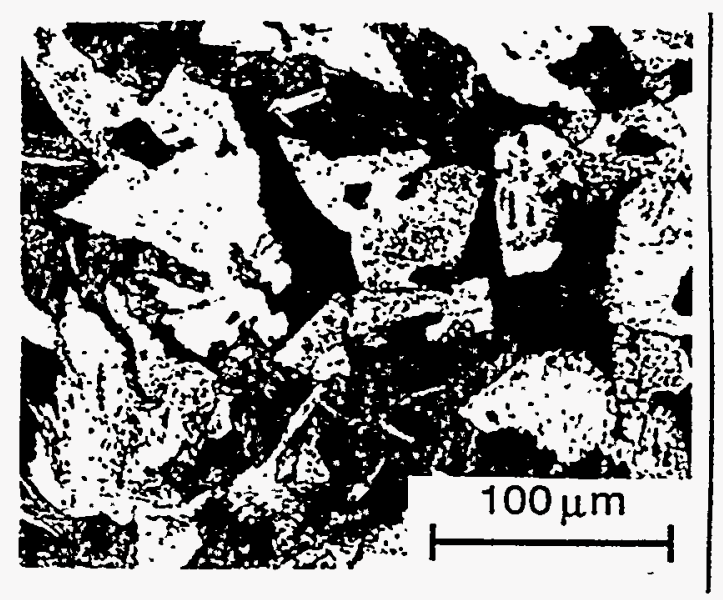

(a)

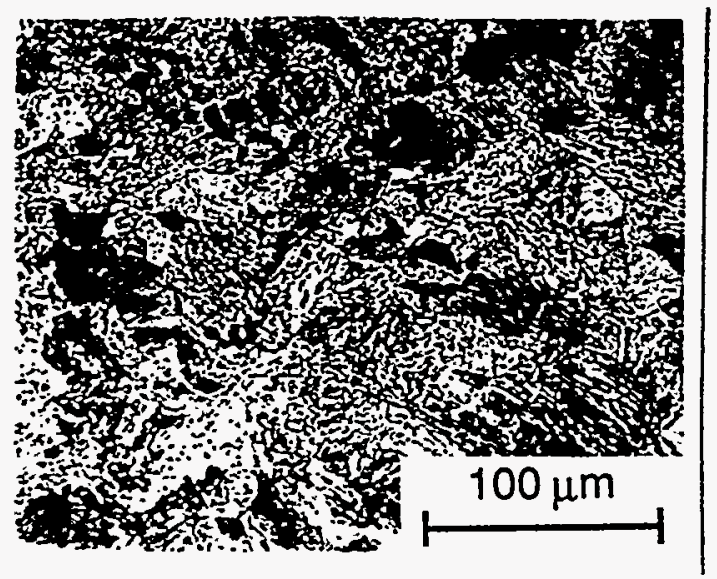

(b)

Figure 1. Microstructures of (a) A106-Gr B carbon steel and (b) A533-Gr B low-alloy steel

An Orbisphere meter and CHEMetrics ${ }^{\mathrm{TM}}$ ampules were used to measure the DO concentrations in the supply and effluent water.

The DO level in water is established by bubbling nitrogen containing $1-2 \%$ oxygen through deionized water in the supply tank. The deionized water is prepared by passing purified water through a set of filters that comprise a carbon filter, a Organex- $Q$ filter, two ion exchangers. and an $0.2 \mu \mathrm{m}$ capsule filter. Water samples were taken periodically to measure $\mathrm{pH}$, resistivity, and DO concentration. After the desired concentration of DO was 


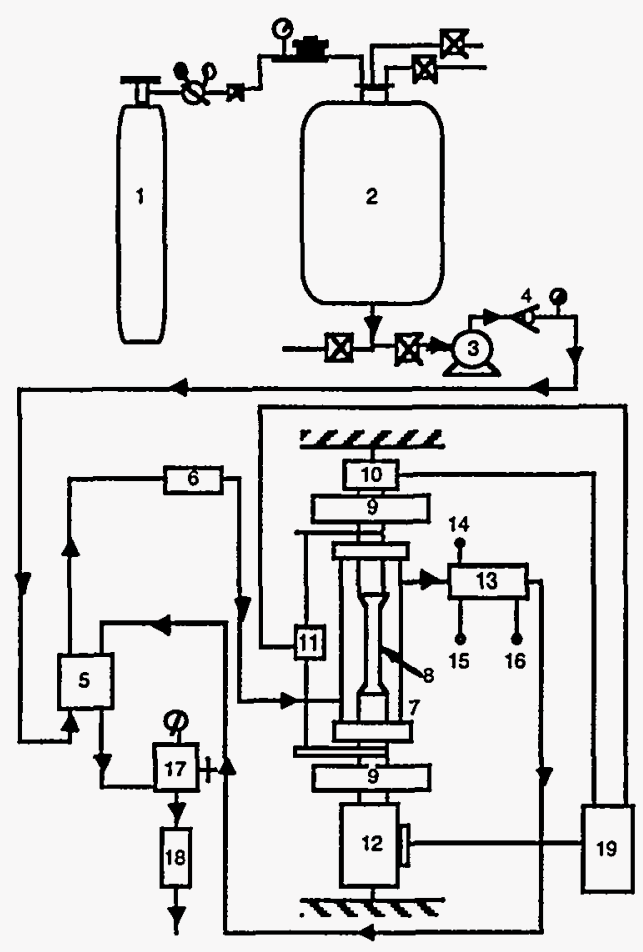

1. Cover gas supply tank

2. Water supply tank

3. Pulsafeeder high-pressure pump

4. Check valve

5. Heat exchanger

6. Preheat exchanger

7. Pipe autoclave

8. Fatigue test specimen

9. MTS hydraulic collet grips

10. MTS load cell

11. Displacement LVDT

12. MTS hydraulic actuator

13. ECP cell

14. Platinum electrode

15. Specimen electrode

16. Reference electrode

17. Mity Mite back-pressure regulator

18. Orbisphere dissolved oxygen meter

19. MTS electrohydraulic controls

Figure 2. Schematic diagram of autoclave system for fatigue tests in water environment

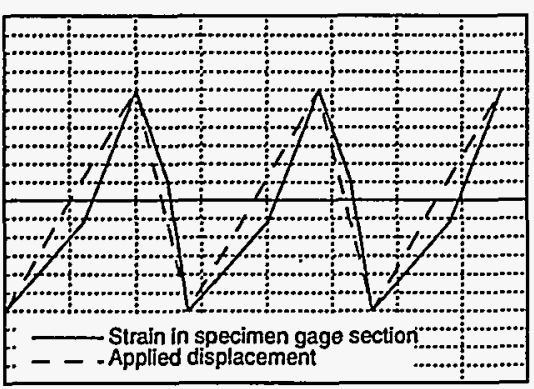

Figure 3. Waveforms for the applied displacement (dashed line) and strain in the specimen gage section (solid line) during a stroke-controlled test

achieved, the nitrogen/oxygen gas mixture was maintained on the supply tank at a 20-kPa overpressure. Simulated PWR water was formulated by dissolving boric acid and lithium hydroxide in $20 \mathrm{~L}$ of deionized water before adding the solution to the supply tank. The $\mathrm{DO}$ in deionized water was reduced to $<10 \mathrm{ppb}$ by bubbling nitrogen through the water. A vacuum was drawn on the tank cover gas to speed deoxygenation. After the DO was reduced to the desired level, a $20-\mathrm{kPa}$ overpressure of hydrogen was maintained to provide $\approx 2 \mathrm{ppm}$ dissolved hydrogen in the feedwater.

All tests were conducted at $288^{\circ} \mathrm{C}$ with fully reversed axial loading (i.e., strain ratio $\mathrm{R}=-1$ ) and a triangular or sawtooth waveform. The strain rate for the triangular wave and fast-loading half of the sawtooth wave was $0.4 \% / \mathrm{s}$. Tests in water were performed under stroke control where the specimen strain was controlled between two locations outside the autoclave. Tests in air were performed under strain control with an axial extensometer; specimen strain between the two locations used in the water tests was also recorded. Information from the air tests was used to determine the stroke required to maintain constant strain in the specimen gage length for tests in water; stroke the stroke is gradually increased during the test to account for cyclic hardening of the material and to maintain constant strain in the specimen gage section. The accuracy of the procedure was checked by conducting stroke-controlled tests in air and monitoring strain in the gage section of the specimen; the differences between estimated and measured strain range were $\pm 2 \%$.

The loading strain that is actually applied to the specimen gage section (solid line) during a stroke-controlled tests with a sawtooth waveform (dashed line) is shown in Fig. 3. However, during the cycle the fraction of applied displacement that goes to the specimen gage section is not constant but varies with the loading strain. Consequently, the loading rate also varies during the fatigue cycle; it is lower than the applied strain rate at strain levels below the elastic limit and higher at larger strains.

\section{AIR ENVIRONMENT}

The fatigue results on A106-Gr B and A533-Gr B steels are summarized in Tables 3 and 4, respectively. Fatigue S-N curves for carbon and low-alloy steels in air are shown in Fig. 4. Fatigue life is defined as the number of cycles $\mathrm{N}_{25}$ for tensile stress to drop $25 \%$ from its peak value; this corresponds to $a=3-$ $\mathrm{mm}$ deep crack in the test specimen. Results from other investi- 
Table 3. Fatigue test results for $A 106-G r B$ carbon steel

\begin{tabular}{|c|c|c|c|c|c|c|c|c|c|}
\hline $\begin{array}{c}\text { Test } \\
\text { Number }\end{array}$ & $\begin{array}{c}\text { Environ- } \\
\text { ment }^{\mathrm{a}}\end{array}$ & $\begin{array}{l}\text { Dissolved } \\
\text { Oxygen } \\
\text { (ppb) }\end{array}$ & $\begin{array}{c}\mathrm{pH} \\
\text { at } \mathrm{RT}\end{array}$ & $\begin{array}{l}\text { Conductivity } \\
(\mathrm{mS} / \mathrm{cm})\end{array}$ & $\begin{array}{l}\text { Tensile } \\
\text { Rate } \\
(\% / \mathrm{s})\end{array}$ & $\begin{array}{l}\text { Comp. } \\
\text { Rate } \\
(\% / s)\end{array}$ & $\begin{array}{l}\text { Stress } \\
\text { Range } \\
(\mathrm{MPa})\end{array}$ & $\begin{array}{c}\text { Strain } \\
\text { Range } \\
(\%)\end{array}$ & $\begin{array}{c}\text { Life } \\
\mathrm{N}_{25} \\
\text { (Cycles) }\end{array}$ \\
\hline 1498 & Air & - & - & - & 0.4 & 0.4 & 1001.4 & 1.004 & 1,048 \\
\hline 1546 & Air & - & - & - & 0.4 & 0.4 & 975.7 & 0.916 & 1,365 \\
\hline 1553 & Air & - & - & - & 0.4 & 0.4 & 921.1 & 0.757 & 3,253 \\
\hline 1554 & Air & - & - & - & 0.4 & 0.4 & 896.8 & 0.730 & 3,753 \\
\hline $1674^{b}$ & Air & - & - & - & 0.4 & 0.4 & 1003.6 & 0.764 & 6,275 \\
\hline $1686^{b}$ & Air & - & - & - & 0.4 & 0.4 & 1017.2 & 0.804 & 2,592 \\
\hline 1731 & Air & - & - & - & 0.4 & 0.004 & 1005.5 & 0.758 & 3,485 \\
\hline 1615 & Air & - & - & - & 0.04 & 0.4 & 959.8 & 0.755 & 3,873 \\
\hline 1609 & Air & - & - & - & 0.004 & 0.4 & 1026.0 & 0.756 & 3,721 \\
\hline 1612 & Air & - & - & - & 0.004 & 0.4 & 1008.2 & 0.779 & 3,424 \\
\hline 1673 & Air & - & - & - & 0.004 & 0.4 & 1003.6 & 0.759 & 6,275 \\
\hline 1548 & Air & - & - & - & 0.4 & 0.4 & 831.9 & 0.545 & 10,632 \\
\hline 1543 & Air & - & - & - & 0.4 & 0.4 & 818.2 & 0.502 & 14,525 \\
\hline 1619 & Air & - & - & - & 0.4 & 0.4 & 741.7 & 0.401 & 37,142 \\
\hline $1636^{c}$ & Air & - & - & - & 0.4 & 0.4 & 749.6 & 0.402 & 34,829 \\
\hline 1621 & Air & - & - & - & 0.01 & 0.4 & 787.1 & 0.403 & 38,128 \\
\hline $1638^{d}$ & Air & - & - & - & 0.4 & 0.4 & 800.0 & 0.436 & 26,728 \\
\hline 1550 & Air & - & - & - & 0.4 & 0.4 & 681.7 & 0.353 & 66,768 \\
\hline 1552 & Air & - & - & - & 0.4 & 0.4 & 680.6 & 0.352 & 93,322 \\
\hline 1555 & Air & - & - & - & 0.4 & 0.4 & 676.3 & 0.343 & 98,456 \\
\hline 1644 & Air & - & - & - & 0.004 & 0.4 & 702.0 & 0.364 & $>94,657$ \\
\hline $1738^{e}$ & DI & 1 & 6.5 & 0.09 & 0.004 & 0.4 & 976.2 & 0.777 & 1,350 \\
\hline $1744^{\mathrm{e}}$ & DI & $<1$ & 6.5 & 0.08 & 0.4 & 0.4 & 760.5 & 0.414 & 19,860 \\
\hline 1547 & PWR & 8 & 6.7 & 23.26 & 0.4 & 0.4 & 1010.9 & 0.987 & 692 \\
\hline 1564 & PWR & 12 & 6.6 & 21.74 & 0.4 & 0.4 & 942.0 & 0.769 & 1,525 \\
\hline 1676 & PWR & 2 & 6.5 & 20.83 & 0.4 & 0.4 & 926.7 & 0.741 & 2,230 \\
\hline 1679 & PWR & 3 & 6.5 & 20.41 & 0.004 & 0.4 & 1005.8 & 0.763 & 2,141 \\
\hline 1681 & PWR & 1 & 6.5 & 20.00 & 0.0004 & 0.4 & 1015.7 & 0.764 & 2,672 \\
\hline 1549 & PWR & 8 & 6.7 & 25.64 & 0.4 & 0.4 & 827.0 & 0.533 & 9,396 \\
\hline 1560 & PWR & 12 & 6.6 & 23.73 & 0.4 & 0.4 & 701.3 & 0.363 & 35,190 \\
\hline 1556 & PWR & 8 & 6.6 & 22.73 & 0.4 & 0.4 & 710.9 & 0.360 & 38,632 \\
\hline 1632 & Hi DO & 800 & 5.8 & 0.11 & 0.4 & 0.4 & 913.3 & 0.740 & 2,077 \\
\hline 1705 & Hi DO & 650 & 5.9 & 0.15 & 0.4 & 0.4 & 947.9 & 0.767 & 1,756 \\
\hline $1680^{b}$ & Hi DO & 700 & 6.0 & 0.08 & 0.4 & 0.4 & 999.6 & 0.818 & 1,007 \\
\hline $1690^{\mathrm{b}}$ & Hi DO & 700 & 6.0 & 0.08 & 0.4 & 0.4 & 1002.2 & 0.824 & 1,092 \\
\hline $1687^{\mathrm{f}}$ & Hi DO & 700 & 6.0 & 0.10 & 0.4 & 0.4 & 1020.0 & 0.809 & 840 \\
\hline 1693 & Hi DO & 650 & 6.0 & 0.10 & 0.04 & 0.4 & 920.0 & 0.737 & 1,125 \\
\hline 1614 & Hi DO & 400 & 5.9 & 0.11 & 0.004 & 0.4 & 930.4 & 0.786 & 303 \\
\hline 1682 & Hi DO & 700 & 6.0 & 0.09 & 0.004 & 0.4 & 921.1 & 0.746 & 469 \\
\hline 1623 & Hi DO & 800 & 5.9 & 0.08 & 0.004 & 0.004 & 943.8 & 0.792 & 338 \\
\hline 1616 & Hi DO & 800 & 5.8 & 0.08 & 0.0004 & 0.4 & 912.8 & 0.799 & 153 \\
\hline 1620 & Hi DO & 900 & 5.9 & 0.11 & 0.00004 & 0.004 & 943.1 & 0.794 & 161 \\
\hline 1706 & Hi DO & 600 & 5.9 & 0.07 & 0.4 & 0.4 & 825.2 & 0.528 & 7,858 \\
\hline 1634 & Hi DO & 800 & 5.8 & 0.16 & 0.4 & 0.4 & 733.2 & 0.400 & 19,318 \\
\hline $1637^{d}$ & Hi DO & 900 & 5.9 & 0.11 & 0.4 & 0.4 & 788.3 & 0.470 & 16,622 \\
\hline 1624 & Hi DO & 800 & 5.9 & 0.10 & 0.004 & 0.4 & 775.7 & 0.456 & 2,276 \\
\hline 1639 & Hi DO & 800 & 5.9 & 0.09 & 0.004 & 0.4 & 751.6 & 0.418 & 2,951 \\
\hline 1643 & Hi DO & 800 & 6.0 & 0.11 & 0.004 & 0.4 & 698.5 & 0.363 & $>65,000$ \\
\hline
\end{tabular}


Table 4. Fatigue test results for A533-Gr B low-alloy steel

\begin{tabular}{|c|c|c|c|c|c|c|c|c|c|}
\hline $\begin{array}{c}\text { Test } \\
\text { Number }\end{array}$ & $\begin{array}{l}\text { Environ- } \\
\text { ment }^{\mathrm{a}}\end{array}$ & $\begin{array}{l}\text { Dissolved } \\
\text { Oxygen } \\
\text { (ppb) }\end{array}$ & $\begin{array}{c}\mathrm{pH} \\
\text { at RT }\end{array}$ & $\begin{array}{l}\text { Conductivity } \\
(\mathrm{mS} / \mathrm{cm})\end{array}$ & $\begin{array}{c}\text { Tensile } \\
\text { Rate } \\
(\% / s)\end{array}$ & $\begin{array}{l}\text { Comp. } \\
\text { Rate } \\
(\% / s)\end{array}$ & $\begin{array}{l}\text { Stress } \\
\text { Range } \\
\text { (MPa) }\end{array}$ & $\begin{array}{c}\text { Strain } \\
\text { Range } \\
(\%)\end{array}$ & $\begin{array}{c}\text { Life } \\
\mathrm{N}_{25} \\
\text { (Cycles) }\end{array}$ \\
\hline 1508 & Air & - & $\overline{-}$ & $\overline{-}$ & 0.4 & 0.4 & 910.9 & 1.002 & 3,305 \\
\hline 1524 & Air & - & - & - & 0.4 & 0.4 & 892.3 & 0.950 & 3,714 \\
\hline 1523 & Air & - & - & - & 0.4 & 0.4 & 898.6 & 0.917 & 2,206 \\
\hline 1521 & Air & - & - & - & 0.4 & 0.4 & 889.4 & 0.910 & 3,219 \\
\hline 1522 & Air & - & - & - & 0.4 & 0.4 & 905.4 & 0.899 & 3,398 \\
\hline 1515 & Air & - & - & - & 0.4 & 0.4 & 866.1 & 0.752 & 6,792 \\
\hline 1717 & Air & - & - & - & 0.4 & 0.004 & 884.6 & 0.758 & 6,217 \\
\hline 1625 & Air & - & - & - & 0.004 & 0.4 & 887.7 & 0.757 & 4,592 \\
\hline $1629^{b}$ & Air & - & - & - & 0.4 & 0.4 & 782.9 & 0.503 & 31,243 \\
\hline 1590 & Air & - & - & - & 0.4 & 0.004 & 821.1 & 0.503 & 24,471 \\
\hline 1576 & Air & - & - & - & 0.004 & 0.4 & 805.8 & 0.503 & 28,129 \\
\hline 1505 & Air & - & - & - & 0.4 & 0.4 & 767.6 & 0.501 & 31,200 \\
\hline 1525 & Air & - & - & - & 0.4 & 0.4 & 743.6 & 0.452 & 65,758 \\
\hline 1640 & Air & - & - & - & 0.4 & 0.4 & 710.9 & 0.402 & 65,880 \\
\hline 1538 & Air & - & - & - & 0.4 & 0.4 & 708.0 & 0.387 & $>1,000,000$ \\
\hline 1517 & Air & - & - & - & 0.4 & 0.4 & 692.5 & 0.353 & $2,053,295$ \\
\hline 1659 & Air & - & - & - & 0.004 & 0.4 & 656.2 & 0.343 & $>114,294$ \\
\hline 1526 & DI & - & - & - & 0.4 & 0.4 & 876.4 & 0.873 & 3,332 \\
\hline 1527 & DI & - & 6.0 & - & 0.4 & 0.4 & 752.8 & 0.493 & 10,292 \\
\hline 1528 & DI & 5 & 5.8 & - & 0.4 & 0.4 & 744.1 & 0.488 & 25,815 \\
\hline $1743^{c}$ & DI & $<1$ & 6.5 & 0.08 & 0.4 & 0.4 & 712.6 & 0.386 & 84,700 \\
\hline 1530 & PWR & 3 & 6.9 & 41.67 & 0.4 & 0.4 & 885.5 & 0.894 & 1,355 \\
\hline 1545 & PWR & 8 & 6.9 & 22.73 & 0.4 & 0.4 & 889.7 & 0.886 & 3,273 \\
\hline 1533 & PWR & 4 & 6.9 & 45.45 & 0.004 & 0.4 & 916.0 & 0.774 & 3,416 \\
\hline 1529 & PWR & 3 & 6.9 & 45.45 & 0.4 & 0.4 & 743.4 & 0.484 & 31,676 \\
\hline 1605 & PWR & 9 & 6.5 & 23.81 & 0.4 & 0.004 & 785.2 & 0.460 & $>57,443$ \\
\hline 1588 & PWR & 6 & 6.5 & 23.26 & 0.004 & 0.4 & 828.7 & 0.514 & 15,321 \\
\hline 1539 & PWR & 6 & 6.8 & 38.46 & 0.4 & 0.4 & 690.9 & 0.373 & 136,570 \\
\hline 1542 & PWR & 6 & 6.6 & 27.03 & 0.4 & 0.4 & 631.8 & 0.354 & $>1,154,892$ \\
\hline 1645 & Hi DO & 800 & 6.1 & 0.07 & 0.4 & 0.4 & 831.1 & 0.721 & 2,736 \\
\hline 1626 & Hi DO & 900 & 5.9 & 0.13 & 0.004 & 0.4 & 910.1 & 0.788 & 247 \\
\hline 1715 & Hi DO & 600 & 5.9 & 0.08 & 0.004 & 0.4 & 904.1 & 0.813 & 381 \\
\hline 1711 & Hi DO & 630 & 5.8 & 0.31 & 0.4 & 0.4 & 772.1 & 0.542 & 5,850 \\
\hline 1707 & Hi DO & 650 & 5.9 & 0.08 & 0.4 & 0.004 & 803.0 & 0.488 & 3,942 \\
\hline 1709 & Hi DO & 650 & 5.9 & 0.11 & 0.4 & 0.004 & 805.1 & 0.501 & 3,510 \\
\hline 1627 & Hi DO & 800 & 5.9 & 0.10 & 0.004 & 0.4 & 826.8 & 0.534 & 769 \\
\hline 1641 & Hi DO & 800 & 5.9 & 0.09 & 0.4 & 0.4 & 693.0 & 0.385 & 17,367 \\
\hline 1665 & Hi DO & 800 & 6.1 & 0.08 & 0.004 & 0.4 & 717.0 & 0.376 & 3,455 \\
\hline 1666 & Hi DO & 750 & 6.1 & 0.09 & 0.0004 & 0.4 & 729.6 & 0.376 & $>7,380$ \\
\hline 1647 & Hi DO & 800 & 6.1 & 0.09 & 0.4 & 0.4 & 688.0 & 0.380 & 26,165 \\
\hline 1660 & Hi DO & 750 & 6.1 & 0.11 & 0.004 & 0.4 & 689.6 & 0.360 & $>83,024$ \\
\hline 1649 & Hi DO & 700 & 6.3 & 0.08 & 0.4 & 0.4 & 673.4 & 0.352 & 28,710 \\
\hline 1652 & Hi DO & 700 & 6.1 & 0.09 & 0.4 & 0.4 & 638.1 & 0.328 & 56,923 \\
\hline 1655 & Hi DO & 750 & 6.1 & 0.10 & 0.4 & 0.4 & 567.6 & 0.289 & $>1,673,954$ \\
\hline
\end{tabular}

${ }^{\mathrm{a}} \mathrm{DI}=$ Deionized water and PWR $=$ simulated PWR water containing $2 \mathrm{ppm}$ lithium and $1000 \mathrm{ppm}$ boron.

${ }^{\mathrm{b}}$ Specimen preoxidized in water with $600 \mathrm{ppb}$ DO for $100 \mathrm{~h}$ at $288^{\circ} \mathrm{C}$.

${ }^{c}$ Prior to being tested in low-DO water, specimen was preoxidized in water with $600 \mathrm{ppb}$ DO for $30 \mathrm{~h}$ at $288^{\circ} \mathrm{C}$.

gations $(7,11)$ on similar steels with comparable composition, in particular sulfur content, and the ASME Section III mean-data curve (at room temperature) are also included in the figures.

The results indicate that for both steels, strain rate has no effect on fatigue life in air. The data for A106-Gr B steel are in good agreement with results obtained by Terrell $(6,7)$ on A106-
$\mathrm{Gr} B$ steel, but are lower by a factor of $\approx 5$ than those obtained by Higuchi and lida (11) on A333-Gr 6 steel. Also, the data for A106-Gr B steel are below the ASME mean curve for carbon steel at high strain ranges (by a factor of 3), but are above the ASME mean curve at low strain ranges. The combined data from the present study and those obtained by Terrell (6) for A106Gr B steel may be expressed by the relationship 

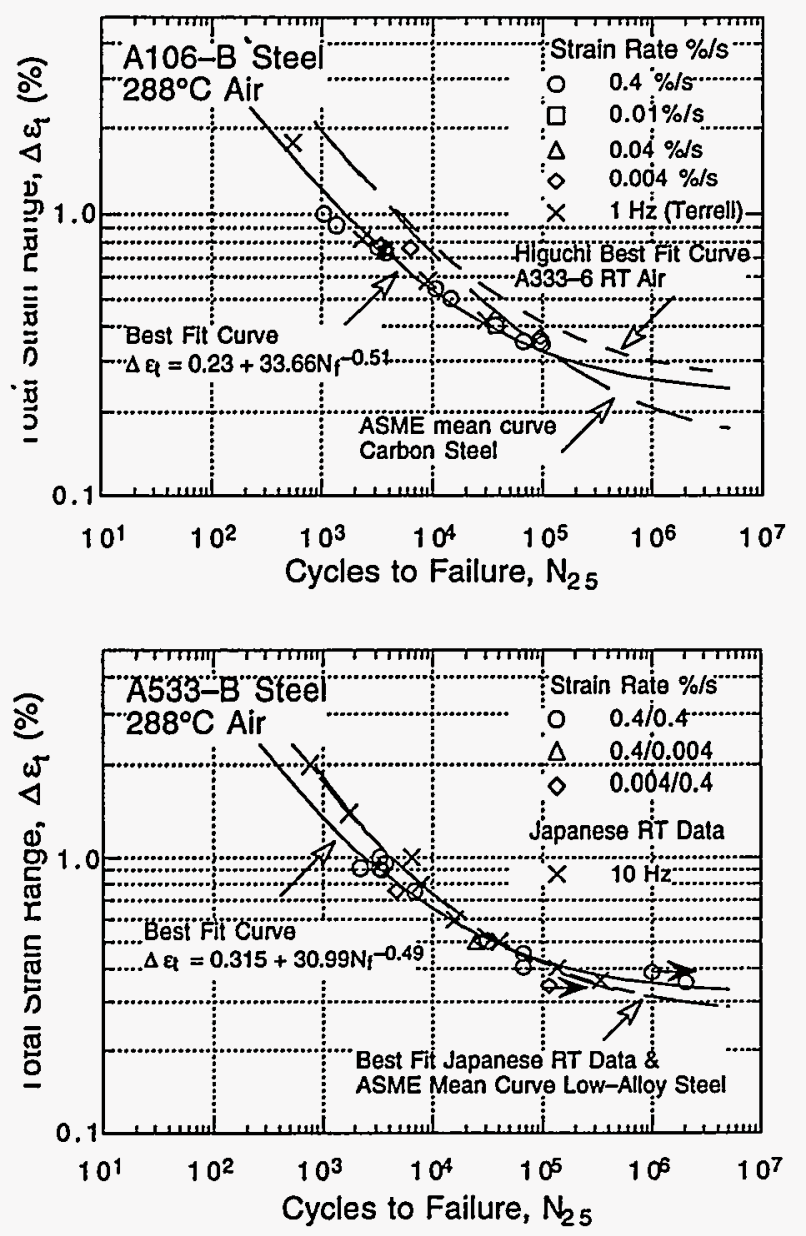

Figure 4. Total strain range vs. fatigue life data for $A 106-G r B$ carbon steel and A533-Gr B low-alloy steel in air

$$
\Delta \varepsilon_{\mathrm{t}}=0.230+33.66 \mathrm{~N}_{25}{ }^{-0.51} \text {. }
$$

The results for A533-Gr B steel show good agreement with the ASME mean-data curve for low-alloy steel at room temperature and JNUFAD ${ }^{*}$ data on A533-Gr B steel. The ANL data for A533-Gr B steel may be expressed by the relationship

$$
\Delta \varepsilon_{\mathrm{t}}=0.315+30.99 \mathrm{~N}_{25}{ }^{-0.49}
$$

These equations provide reference fatigue $\mathrm{S}-\mathrm{N}$ behavior in air for the ANL heats of A106-Gr B and A533-Gr B steels.

\section{ALLOY COMPOSITION}

The cyclic-hardening behaviors of carbon and low-alloy steels are significantly different. Plots of cyclic stress range vs. fatigue cycles for A106-Gr B and A533-Gr B steels tested in air

\footnotetext{
* Private communication from M. Higuchi, Ishikawajima-Harima Heavy Industries Co., Japan, to M. Prager of the Pressure Vessel Research Council, 1992.
}

at $288^{\circ} \mathrm{C}$ and total strain ranges of $\approx 0.75 \%$ and $\approx 0.35 \%$ are shown in Figs. 5 and 6, respectively. Cyclic strain-hardening of the steels is consistent with their microstructure. The A106-Gr B steel, with a pearlitic structure and low yield stress, exhibits rapid hardening during the initial 100 cycles of fatigue life. The extent of hardening increases with applied strain range. In contrast, the A533-Gr B low-alloy steel consists of a tempered bainitic structure, has a relatively high yield stress, and shows little or no initial hardening. At low strain ranges, the A533-Gr B steel shows cyclic softening during the initial 100 cycles of fatigue life (Fig. 6). Furthermore, the A106-Gr B carbon steel exhibits dynamic strain aging. Consequently, cyclic stress of carbon steel increases significantly with decreasing strain rate. Because of its tempered bainitic structure, the low-alloy steel exhibits little or no dynamic strain aging.

The cyclic stress vs. strain curves for A106-Gr B and A533-Gr B steels at $288^{\circ} \mathrm{C}$ are shown in Fig. 7; cyclic stress corresponds to the value at half life. For water environments, only the tests that exhibit a marginal ( $\approx$ factor of 2 ) decrease in fatigue life, e.g., tests in simulated PWR environments or in high-DO water at high strain rates, are shown in Fig. 7. Because of de-
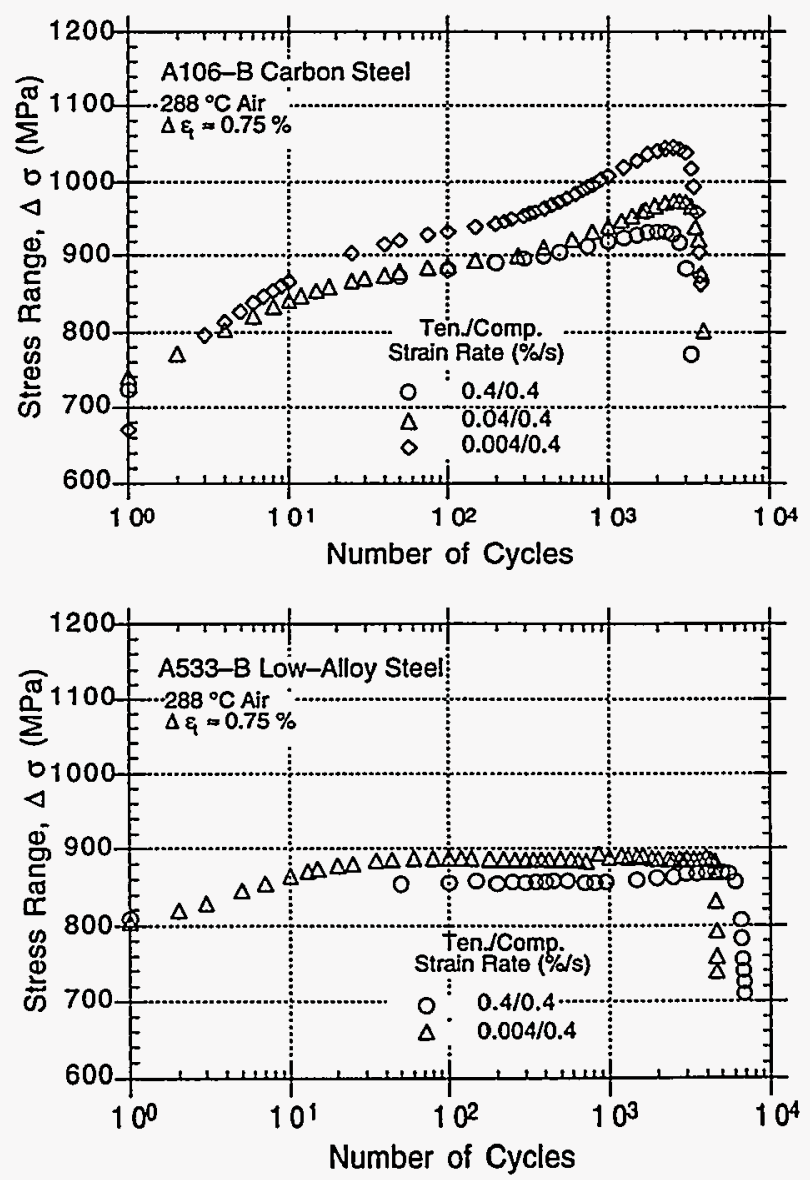

Figure 5. Effect of strain rate on cyclic strain-hardening behavior of $A 106-G r B$ and $A 533-G r B$ steels in air at $288^{\circ} \mathrm{C}$ and $\approx 0.75 \%$ strain range 


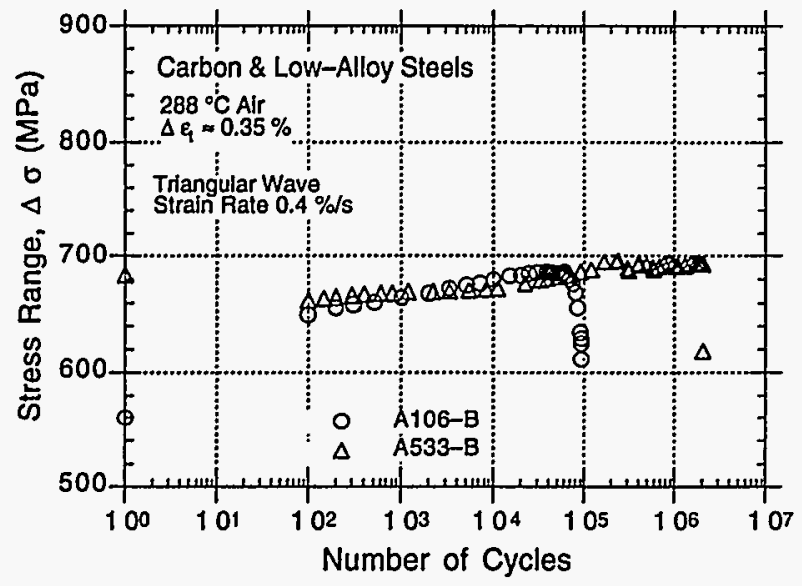

Figure 6. Cyclic strain-hardening behavior of A106-Gr B and A533-Gr B steels at $288^{\circ} \mathrm{C}, 0.35 \%$ strain range, and $0.4 \% / s$ strain rate in air
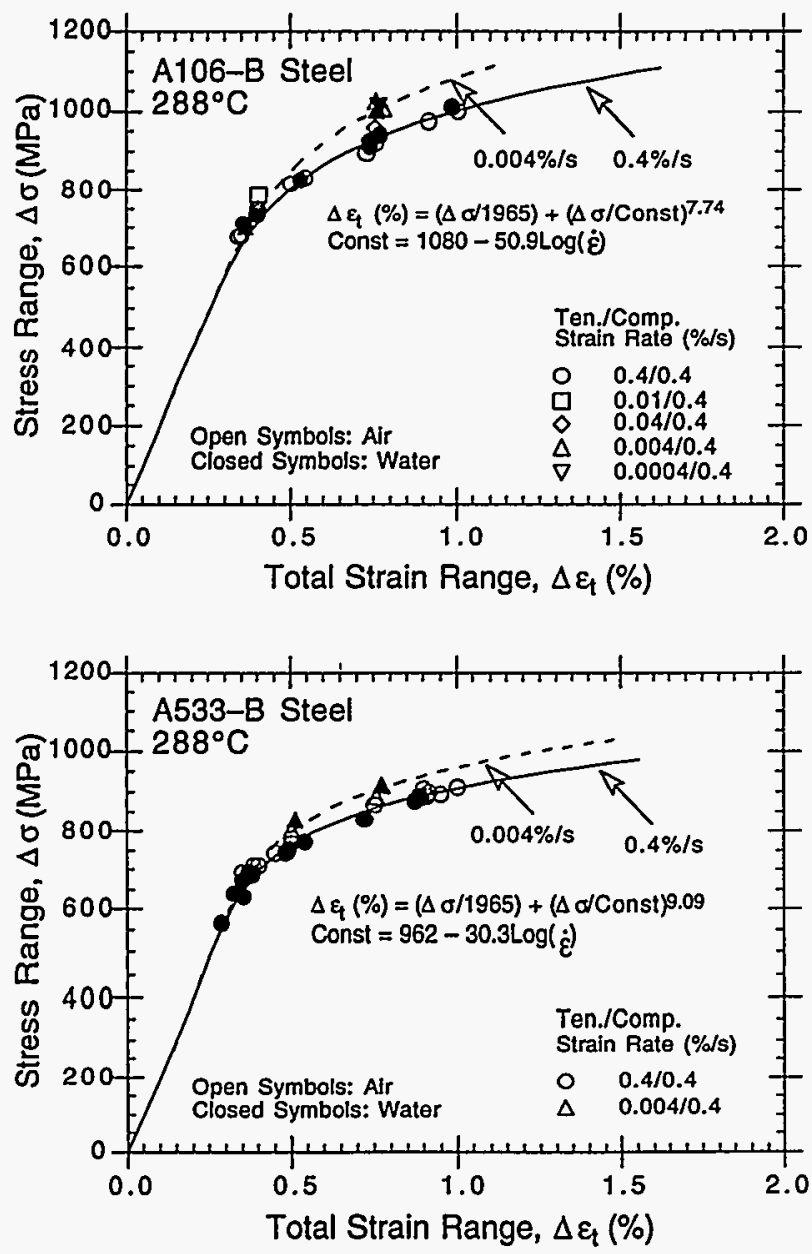

Figure 7. Cyclic stress-strain curve for A106-GrB and A533Gr $B$ steels at $288^{\circ} \mathrm{C}$ in air and water environments creased fatigue life of the tests in high-DO water and slow strain rates, the specimens fail before the onset of dynamic strain aging and, for these tests, cyclic stresses at half life are significantly lower than that for the other tests (fatigue data in water are presented in next sections). The results for A106-Gr B steel show excellent agreement with the data obtained by Terrell $(6,7)$. The total strain range $\Delta \varepsilon_{t}(\%)$ can be expressed in terms of the cyclic stress range (MPa) with the equation

$$
\Delta \varepsilon_{\mathrm{t}}=\frac{\Delta \sigma}{1965}+\left(\frac{\Delta \sigma}{\mathrm{C}}\right)^{7.74}
$$

where the constant $\mathrm{C}$ depends on applied strain rate $\dot{\varepsilon}(\% / \mathrm{s})$ and is expressed as

$$
\mathrm{C}=1080-50.9 \log (\dot{\varepsilon}) .
$$

The best-fit stress vs. strain curve for A533-Gr B steel can be represented with the equation

$$
\Delta \varepsilon_{\mathrm{t}}=\frac{\Delta \sigma}{1965}+\left(\frac{\Delta \sigma}{D}\right)^{9.09} \text {. }
$$

where the constant $\mathrm{D}$ is expressed as

$$
\mathrm{D}=962-30.3 \log (\dot{\varepsilon}) \text {. }
$$

Crack propagation behavior is also different for the carbon and low-alloy steels. Micrographs of fatigue cracks along longitudinal sections of the A106-Gr B and A533-Gr B steel specimens are shown in Fig. 8. In the carbon steel, fatigue cracks propagate preferentially along the soft ferrite grains. The lowalloy steel exhibits a typical straight fatigue crack propagating normal to the stress axis.
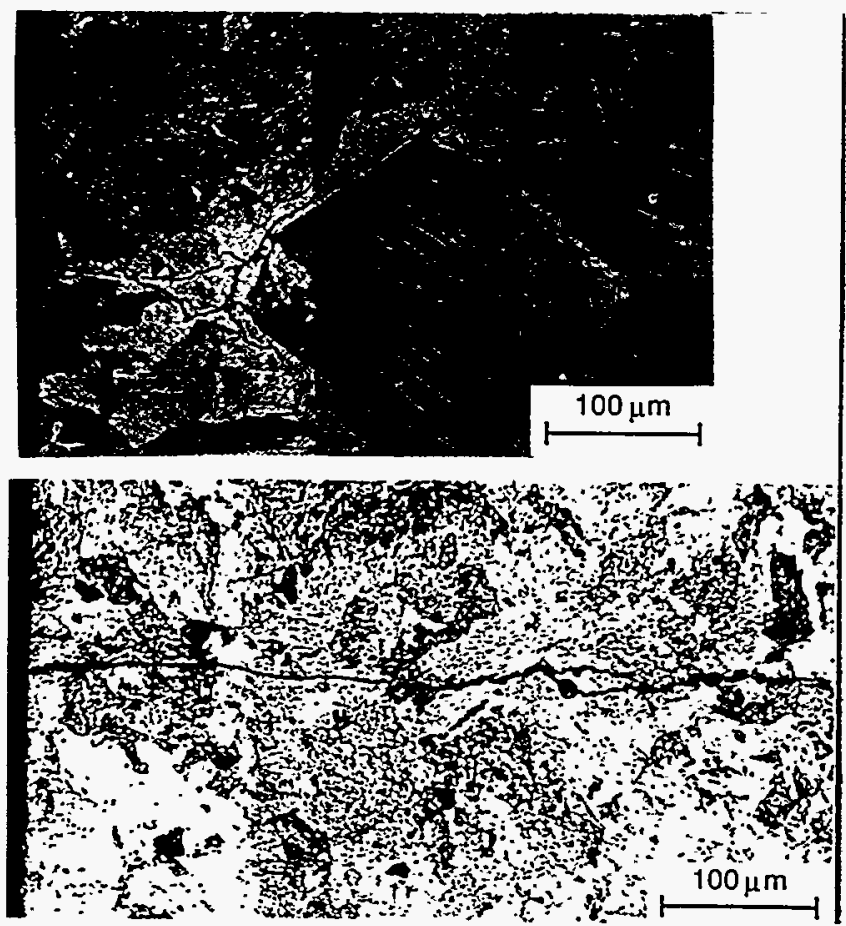

Figure 8. Micrographs of fatigue cracks along longitudinal section of A 106-Gr B and A533-Gr B specimen 
Carbon or low-alloy steel specimens develop similar surface oxide films either in air or in oxygenated water environments. In general, the specimens tested in air show slight discoloration, while the specimens tested in oxygenated water develop a gray/black corrosion scale and are covered with surface deposits. $\mathrm{X}$-ray diffraction analysis of the surfaces indicated that for both steels, the corrosion scale is primarily magnetite $\left(\mathrm{Fe}_{3} \mathrm{O}_{4}\right)$ in simulated PWR water but may also contain some hematite $\left(\mathrm{Fe}_{2} \mathrm{O}_{3}\right)$ after exposure to high-DO water.

\section{SIMULATED PWR ENVIRONMENT}

Figure 9 shows the fatigue $S-N$ plots for A106-Gr B and A533-Gr B steels in simulated PWR water containing $<10 \mathrm{ppb}$ DO, $1000 \mathrm{ppm}$ boron, and $2 \mathrm{ppm}$ lithium. The results indicate a marginal effect of PWR water on fatigue life at high strain ranges. At strain ranges $>0.5 \%$, fatigue lives of both steels in PWR water are lower than those in air by a factor of less than 2. Furthermore, a decrease in the strain rate by three orders of magnitude does not cause an additional decrease in fatigue life. The results for A 106-Gr B steel are consistent with the data obtained by Terrell (7) in simulated PWR water where little or no effect of strain rate or environment on fatigue life was observed. The results are also consistent with the data of Iida et al. (12) and Prater and Coffin $(15,16)$, in which the effects of environment were minimal at $\mathrm{DO}$ levels of $<100 \mathrm{ppb}$.

\section{WATER WITH HIGH DISSOLVED OXYGEN}

\section{Strain Rate}

The total strain range vs. fatigue life plots for A106-Gr B and $A 533-\mathrm{Gr} B$ steels in water containing $0.5-0.8 \mathrm{ppm} \mathrm{DO}$ are shown in Fig. 10. The results indicate significant reductions in fatigue life and a strong dependence on strain rate. Although the microstructures and cyclic-hardening behaviors of the A106Gr B carbon steel and A533-Gr B low-alloy steel are significantly different, there is little or no difference in environmental degradation of fatigue life of these steels. For both steels, fatigue life decreases rapidly with decreasing strain rate. Compared with tests in air, fatigue life of A106-Gr B steel in high-DO water is lower by factors of $2,4,10$, and 18 at strain rates of $0.4,0.04$, 0.004 , and $0.0004 \% / \mathrm{s}$, respectively. A further decrease in strain rate to $0.00004 \% / s$ does not cause additional decrease in fatigue life. The relative reduction in fatigue life is about the same whether the total strain range is 0.75 or $0.4 \%$.

The low-alloy A533-Gr B steel shows an identical behavior. For similar test conditions, the absolute values of fatigue life for A533-Gr B low-alloy steel are comparable to those for A106-Gr B carbon steel. However, because life in air for A533$\mathrm{Gr} B$ steel is greater than that for $\mathrm{A} 106-\mathrm{Gr} B$ steel, the relative reduction in life for the low-alloy steel is larger than that for carbon steel. This is particularly true at low strain range $(0.4 \%)$, where even at the high strain rate, fatigue life is a factor of $\approx 10$ lower than in air. These results are different than the Japanese
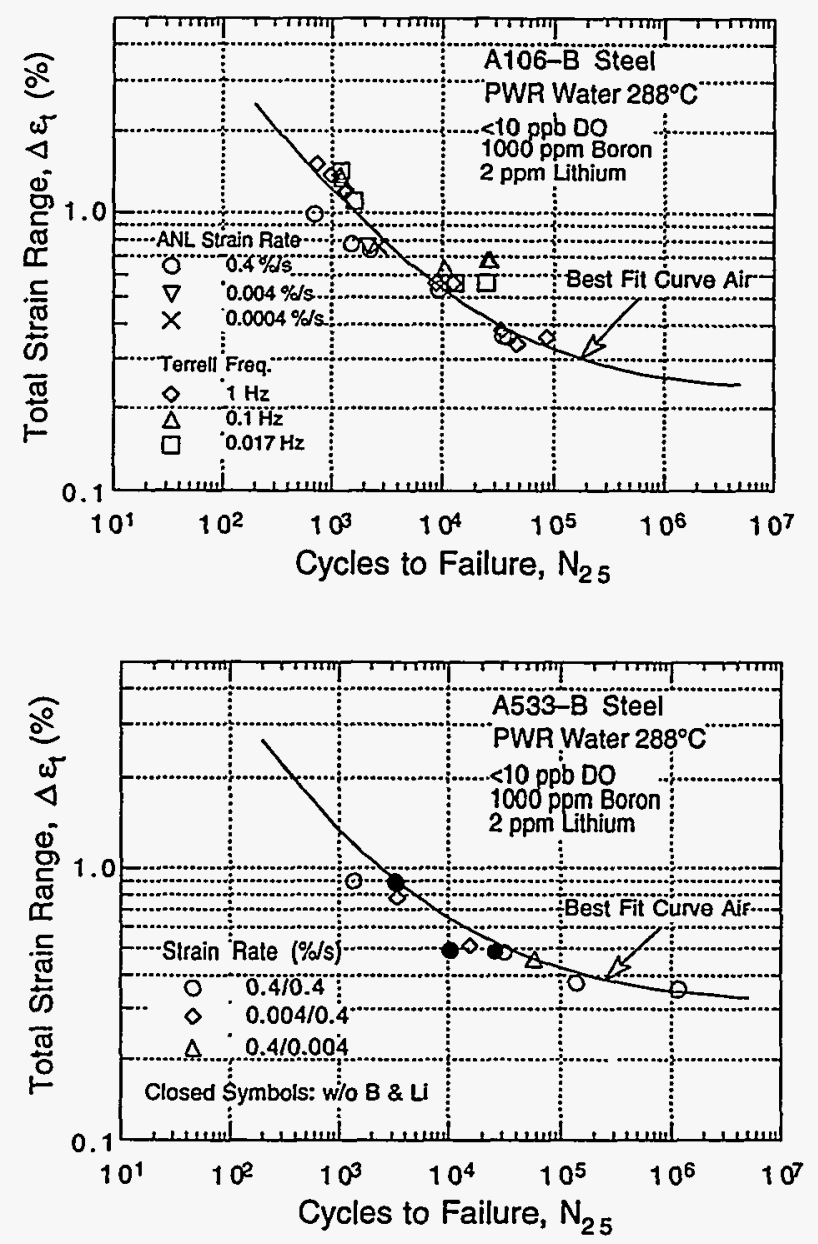

Figure 9. Srain range vs. fatigue life data for A106-Gr $B$ and A533-Gr B steels in simulated PWR water at $288^{\circ} \mathrm{C}$

data compiled in the JNUFAD data base for "Fatigue Strength of Nuclear Plant Component," which indicate that environmental effects on fatigue life are greater for carbon than for low-alloy steel. However, most low-alloy steels that have been investigated in JNUFAD are low-sulfur heats, e.g., <0.007 wt.\%. It is likely that differences between these two steels are caused by the sulfur content of the steels and that compositional or structural differences have only minor effects. The effects of various loading variables on fatigue life of ferritic steels in high-DO water are discussed below.

The relative fatigue lives of several heats of carbon and low-alloy steels are plotted as a function of strain rate in Fig. 11. Relative fatigue life is the ratio of life in water to life of that specific heat in air. The results indicate that in addition to the dependence on strain rate, environmental effects on fatigue life of carbon and low-alloy steels also depend on DO level in water and sulfur content in the steel. Fatigue life of these steels in high-DO water decreases with decreasing strain rates and increasing levels of DO and sulfur. The effect of strain rate on fatigue life appears to saturate at $=0.001 \% / \mathrm{s}$ strain rate. 

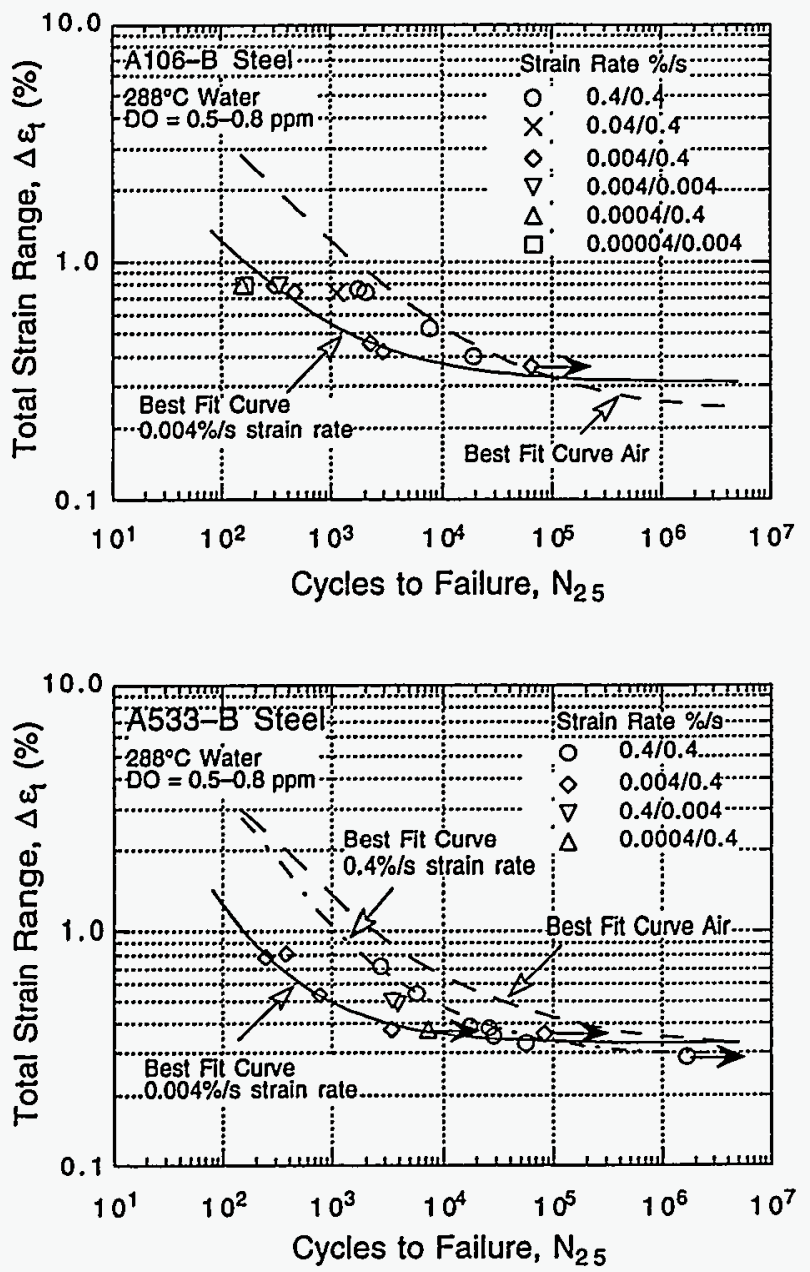

Figure 10. Total strain range vs. fatigue life data for A106-Gr $B$ and A533-Gr B steels in high-DO water at $288^{\circ} \mathrm{C}$

The very-high-sulfur A516-Gr 70 carbon steel $(0.033$ wt.\% sulfur) from the GE tests at the Dresden 1 reactor (3) shows the most severe environmental degradation. For this steel at a given strain rate, the reduction in fatigue life at $0.2 \mathrm{ppm} D O$ is greater by a factor of $\approx 2$ than that for the A106-Gr B steel at $0.8 \mathrm{ppm} \mathrm{DO}$ and for the A333-Gr 6 steel at $0.2 \mathrm{ppm} \mathrm{DO}$. It is unclear whether this difference is due to the extremely high sulfur level in this heat or to the loading waveform used in the Dresden tests. These tests were conducted with a trapezoidal waveform instead of the sawtooth and triangular waveforms used in the ANL and Japanese studies. The trapezoidal waveform consists of hold periods at peak tensile and compressive strains. As discussed later, a hold period at peak tensile stress also decreases fatigue life. In Fig. 11, the data points for this steel will move to the left when the contributions of the hold periods are considered.

The results presented in Fig. 10 also indicate that a slow strain rate applied during the tensile-loading cycle (slow/fast test) is more effective in environmentally assisted reduction in fatigue life than when applied during the compressive-loading cycle (fast/slow test), and that slow strain rate applied during the compressive- and tensile-loading cycles (slow/slow test) does not cause further decrease in fatigue life. Two fatigue tests on A106Gr B steel at a strain range of $=0.75 \%$, one with a slow/fast waveform (i.e., 0.004 and $0.4 \% / \mathrm{s}$ strain rates, respectively, during the tensile and compressive half of the loading cycle) and the other with a slow/slow waveform (i.e., $0.004 \% / s$ constant strain rate), show identical fatigue lives. However, two fatigue tests on A $533-\mathrm{Gr} B$ steel at $\approx 0.5 \%$ strain range and fast/slow waveform (shown as inverted triangles in Fig. 10) do show a somewhat larger decrease in fatigue life than for a fast/fast test, namely, a factor of 8 decrease in life for the fast/slow test compared, to a factor of 5 decrease for the fast/fast test.

\section{Strain Range}

The fatigue data in high-DO water indicate that a minimum strain is required for environmentally assisted decrease in fatigue life. This threshold value of strain range for the ANL heats of carbon and low-alloy steels appears to be at $=0.36 \%$; fatigue tests on A106-Gr B and A533-Gr B steels at $\approx 0.36 \%$ strain
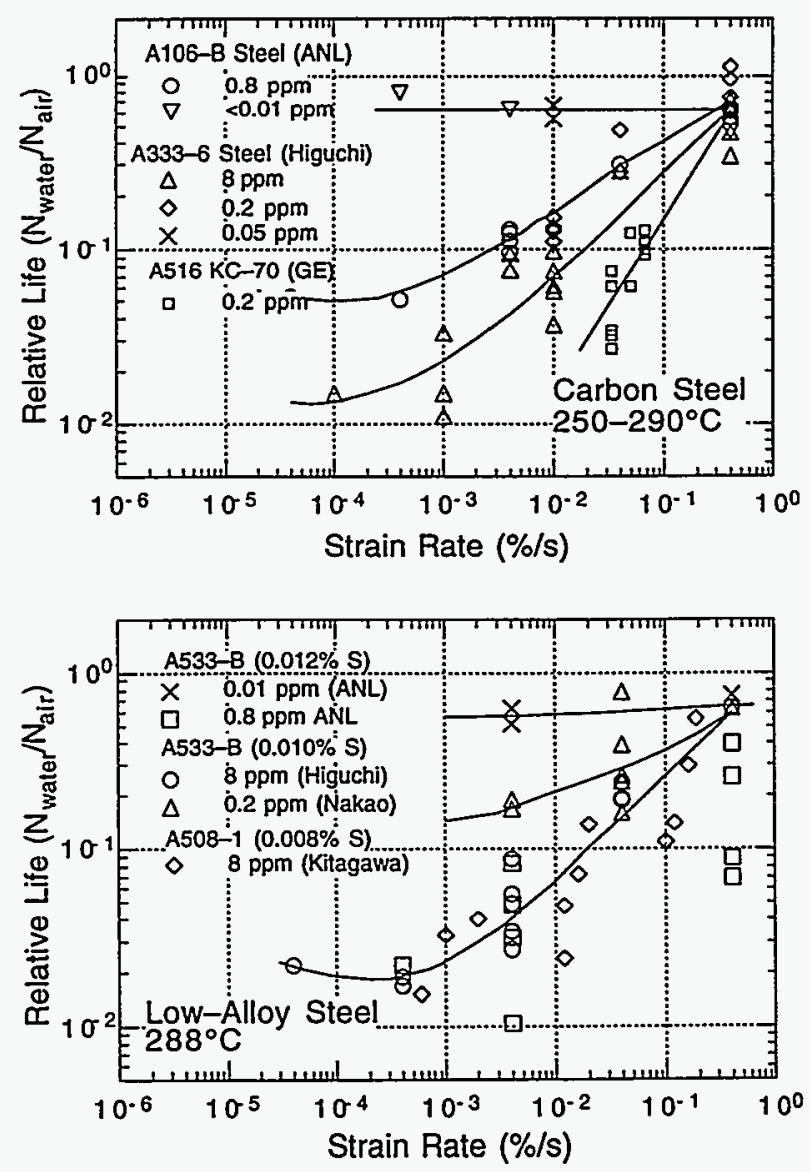

Figure 11. Relative fatigue life of several heats of carbon and low-alloy steels at different levels of dissolved oxygen and strain rate 

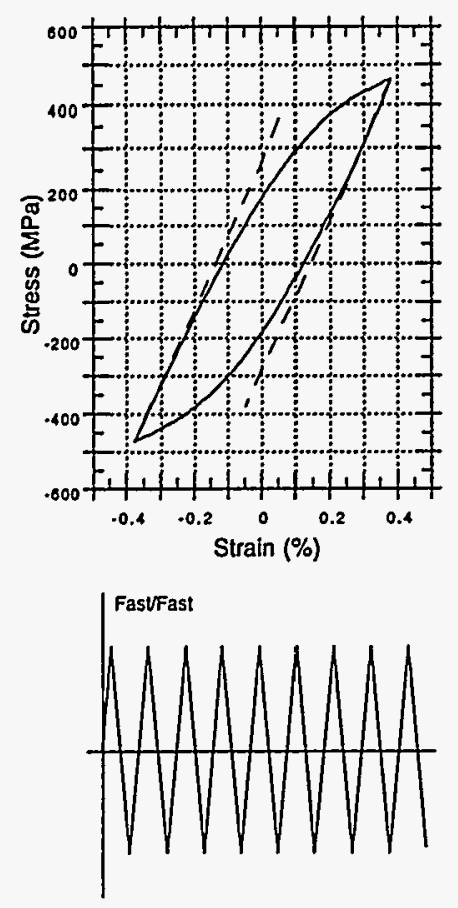

$\begin{array}{ll}\text { Strain or Stroke Control } \\ \text { Air } & : 4740 \pm 1250 \\ \text { PWR } & : 1965 \pm 385 \\ \text { Hi DO } & : 2077\end{array}$
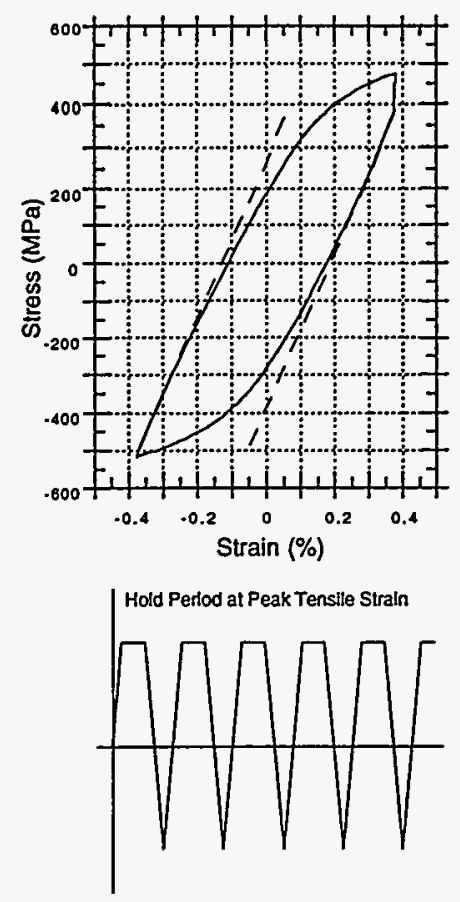

Strain Control

Air
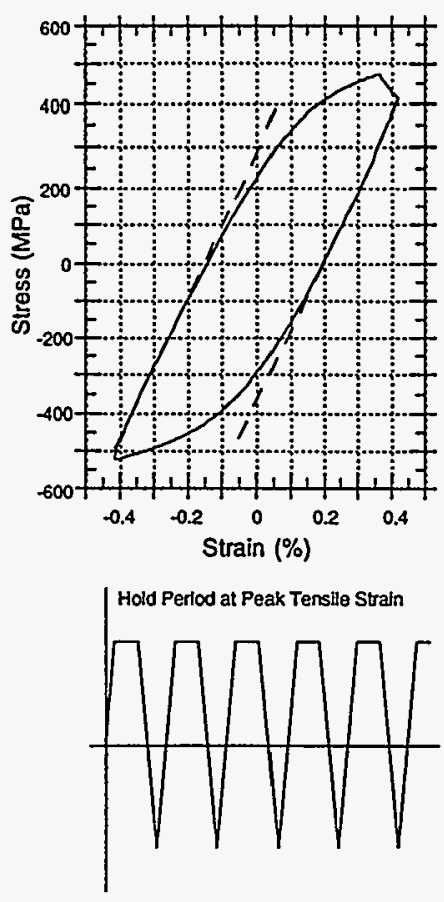

Stroke Control (5 min. hold)

$$
\begin{array}{ll}
\text { Air } & : 2,592 \\
\text { Hi DO } & : 1,007,1,092
\end{array}
$$

Stroke Control (30 min. hold)

Hi DO : 840

Figure 12. Fatigue life of A106-Gr B steel in air and water environmentsat $288^{\circ} \mathrm{C}, \Rightarrow 0.75 \%$ strain range, and hold periods at peak tensile strain. Hysteresis loops are for the tests in air.

range, $0.6-0.8 \mathrm{ppm} \mathrm{DO}$, and $0.004 \% / \mathrm{s}$ tensile strain rate did not produce failure even after 65,000 and 83,000 cycles, respectively (Fig. 10). Furthermore, the fatigue S-N curves for A106-Gr B steel in air and water environments cross over at low strain ranges, i.e., fatigue life in water is longer than that in air. This apparently different fatigue $\mathrm{S}-\mathrm{N}$ behavior is probably not due to the water environment. It is most likely caused by dynamic strain aging of carbon steels and is observed in Fig. 10 because of the difference in strain rate for the tests in air and water environments. The S-N curve in air is based on tests at $0.4 \% / \mathrm{s}$ strain rate, while the curve in water represents fatigue tests at a slower strain rate of $0.004 \% / \mathrm{s}$. For a specific strain range, fatigue tests in water at slower strain rate show greater dynamic strain aging, higher cyclic stress, lower plastic strain range, and longer life.

\section{Tensile Hold Period}

Tests were also conducted with a 5- or 30-min hold at peak tensile strain. Loading waveforms, hysteresis loops, and fatigue lives for the tests (Fig. 12) indicate that a tensile-hold period decreases fatigue life in high-DO water but not in air. A 5-min hold period is sufficient to reduce fatigue life; a longer hold period results in only slightly decreased life. Two 5-minhold tests at $288^{\circ} \mathrm{C}$ and $=0.8 \%$ strain range in oxygenated water with $0.7 \mathrm{ppm}$ DO gave fatigue lives of 1,007 and 1,092 cycles.
Fatigue life in a 30 -min-hold test was 840 cycles. These tests were conducted in stroke-control mode and are somewhat different than the conventional hold-time test in strain-control mode. In the strain-control test, the total strain in the sample is held constant during the hold period. However, a portion of the elastic strain is converted to plastic strain because of stress relaxation. In a stroke-control test, there is an additional plastic strain in the sample due to relaxation of elastic strain from the load train (Fig. 12). Consequently, these are not true constantstrain-hold periods but include significant strain during the hold period; the measured plastic strains during the hold period were $\approx 0.028 \%$ from relaxation of the gage and $0.05-0.06 \%$ from relaxation of the load train. These conditions result in strain rates of $0.005-0.02 \% / \mathrm{s}$ during the hold period.

\section{Surface Morphology}

The fatigue crack growth behavior of ferritic steels in high-temperature oxygenated water and the effects of sulfur content and loading rate are well known (17-24). Dissolution of $\mathrm{MnS}$ inclusions changes the water chemistry near the crack tip, making it more aggressive. This results in enhanced crack growth rates because either (a) the dissolved sulfides decrease the repassivation rate, which increases the amount of metal dissolution for a given oxide rupture rate; or (b) the dissolved sulfide 


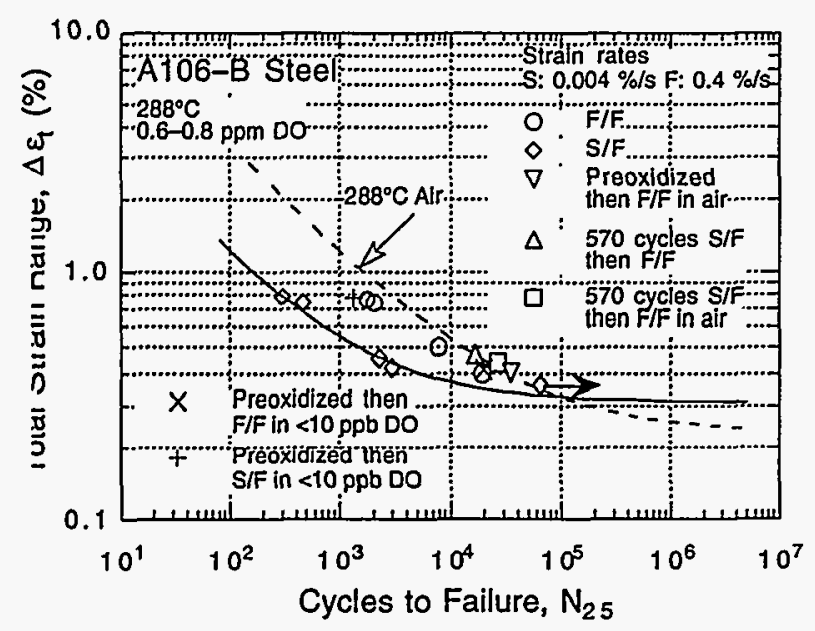

Figure 13. Environmental effects on nucleation of fatigue crack. Preoxidized specimens were exposed at $288^{\circ} \mathrm{C}$ for $30-100 \mathrm{~h}$ in water with $0.6-0.8 \mathrm{ppm}$ DO.

poisons the recombination of $\mathrm{H}$ atoms liberated by corrosion, which enhances $\mathrm{H}$ uptake by the steel at the crack tip.

The water environment may also enhance crack nucleation. For example, corrosion pits or cavities produced by dissolution of MnS inclusions can act as sites for nucleation of fatigue cracks $(25,26)$. A detailed metallographic examination, including measuring the cracking frequency, of the test specimens was conducted to investigate the role of surface micropitting on fatigue crack nucleation. The results have been presented elsewhere (27). All specimens tested in water showed surface micropitting. These pits form either by corrosion of the material in oxygenated water or by selective dissolution of $\mathrm{MnS}$ or other inclusions. However, metallographic examination of the specimens indicates that an oxygenated-water environment has no effect on the nucleation of cracks. There is no indication that fatigue cracks nucleated at any of the surface micropits. Irrespective of environment, cracks in carbon and low-alloy steels nucleate either along slip bands, carbide particles, or at the ferrite/pearlite phase boundaries. The results also show that environment has no effect on the frequency of cracks. For similar loading conditions, the number of cracks in the specimens tested in air and high-DO water are identical, although fatigue life in water is lower by a factor of $\approx 10$.

The contributions of environment to crack nucleation were further evaluated by conducting additional exploratory tests. Figure 13 shows the fatigue life of A106-Gr B steel in air (dashed line) and in high-DO water at 0.4 and $0.004 \% / \mathrm{s}$ strain rates (circle and diamond symbols, respectively). Fatigue tests were conducted on specimens that were preexposed at $288^{\circ} \mathrm{C}$ for 30 $100 \mathrm{~h}$ in water with $0.6-0.8 \mathrm{ppm}$ DO and then tested either in air or low-DO water $(<10 \mathrm{ppb} \mathrm{DO})$. At $0.4 \%$ strain range, nearly half the fatigue life may be spent in crack nucleation. Fatigue lives of the preoxidized specimens are identical to those of unoxidized specimens; life would be expected to decrease if surface micropits facilitate crack nucleation. Similar behavior was observed for preoxidized A533-Gr B specimens.

It is possible that both the high DO and slow strain rate are needed to influence crack nucleation. This possibility was checked by first testing a specimen in high-DO water at $0.4 \%$ strain range and $0.004 \% / s$ strain rate for 570 cycles $\Leftrightarrow 25 \%$ of the life at these loading conditions) and then testing in either air or high-DO water at $0.4 \% / \mathrm{s}$ strain rate. Fatigue life of these tests should be reduced if crack nucleation contributes in any way to environmental effects. Once again, no reduction in life is observed. These results suggest that the reduction in fatigue life in high-DO water is primarily due to environmental effects on fatigue crack propagation. Environment appears to have little or no effect on crack nucleation.

\section{Loading Waveform}

Several exploratory tests were conducted on A106-Gr B and A533-Gr B steels in which a slow strain rate is applied during only a portion of the tensile-loading cycle to check whether each portion of the tensile cycle is equally effective in decreasing fatigue life in high-DO water. The results are presented in Table 5. The loading waveforms and corresponding fatigue lives for the tests on A106-Gr B steel at $=0.75 \%$ strain range are summarized in Fig. 14. The change in fatigue life of A106-Gr B steel with fraction of loading strain at slow strain rate is shown in Fig. 15. Results are shown for slow portions applied near to peak tensile strain (open symbols) or near to peak compressive strain (closed symbols). In stroke-controlled tests, the fraction of loading strain that is actually applied to the specimen gage section is not constant but varies during the cycle. Consequently, for waveforms D and $\mathrm{H}$, although 0.5 of the applied displacement is at a slow rate, the fractions of strain at slow rate in the specimen gage section are 0.334 and 0.666 , respectively. The fraction of loading strain that is actually at slow rate for the various waveforms is shown in Fig. 14.

At $288^{\circ} \mathrm{C}$ and a strain range of $\approx 0.75 \%$, the average fatigue life of A106-Gr B steel in air is $\approx 4000$ cycles. Relative to air, the fatigue lives in simulated PWR water at all strain rates or in high-DO water at high strain rates (i.e., fast/fast tests) are lower by $\approx 50 \%$. If each portion of the tensile-loading cycle was equally effective in reducing fatigue life, the life should decrease linearly from $A$ to $C$ along the cnain-dot line in Fig. 15 and a slow strain rate near peak compressive strain (waveforms $D, E$, or F) should be as equally damaging as a slow strain rate near peak tensile strain (waveforms $\mathrm{H}, \mathrm{I}$, or $\mathrm{J}$ ). The results show that a slow strain rate near peak compressive strain causes no reduction in fatigue life.

As was discussed above in the section on "Strain Range," a minimum amount of strain is required for environmentally assisted decrease in fatigue life. This threshold strain may vary with material and loading conditions such as steel type, temperature, DO, strain ratio, mean stress, etc. For the present study the 
A

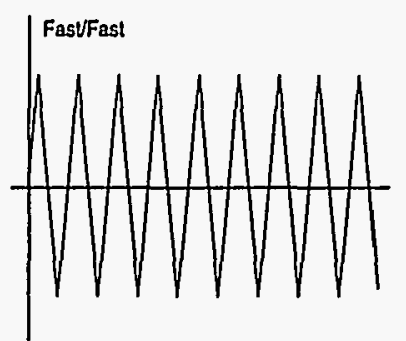

Air:

PWR:

3,$253 ; 3,753$

Hi DO:

B

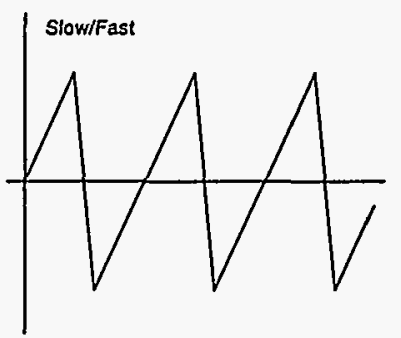

Air: $\quad 3,721 ; 3,424$

6,275

PWR:

Hi DO:

C

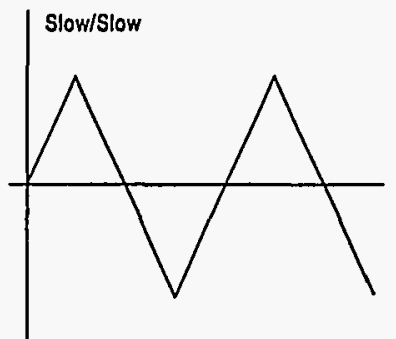

Air:

PWR:

Hi DO:
D

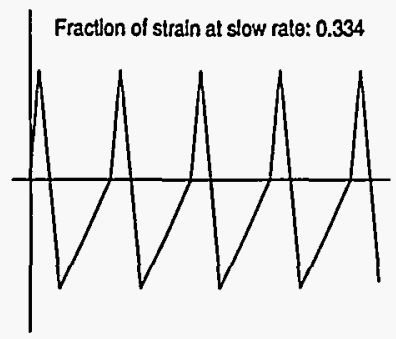

Air:

PWR: -

Hi DO: $\quad 1,935$
H

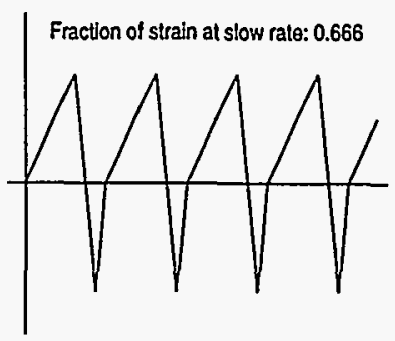

Air:

PWR: $\quad 5,261$

Hi DO: 545
E

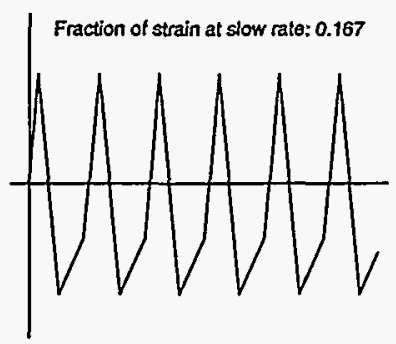

Air: $\quad 4,087$

PWR: $\quad-$

Hi DO: $\quad 1,649 ; 2,080$

F

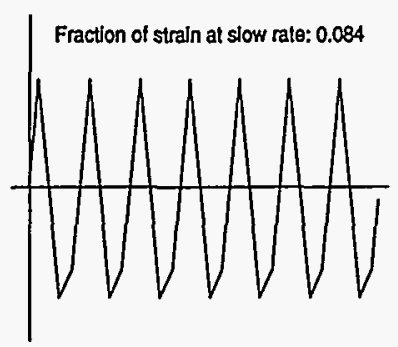

$\begin{array}{ll}\text { Air: } & 4,105 \\ \text { PWR: } & \overline{2} \\ \text { Hi DO: } & 2,093\end{array}$
G

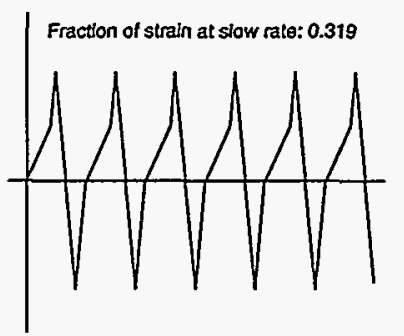

Air: $\quad 5,240$

PWR: $\quad-$

Hi DO: $\quad 1,306$
I

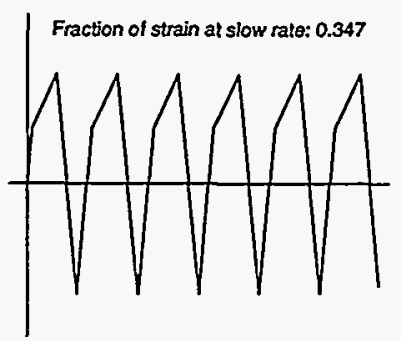

Air: $\quad 5,139$

PWR: $\quad-$

Hi DO: $\quad 615 ; 553$

J

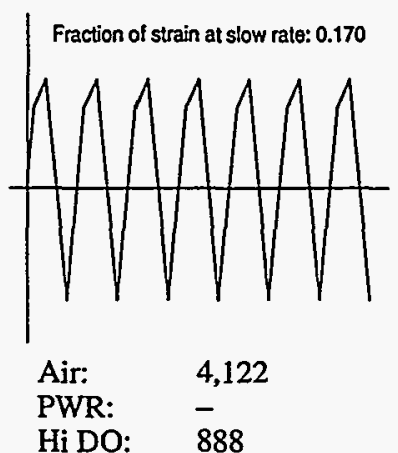

Figure 14. Fatigue life of A106-Gr B carbon steel at $288^{\circ} \mathrm{C}$ and $0.75 \%$ strain range in air and water environments under different loading waveforms

threshold strain range for $A 106-G r B$ carbon steel is $\approx 0.36 \%$. Consequently, a slow strain rate applied during the portion of loading cycle that is below the threshold strain should have no effect on fatigue life. This behavior is consistent with the slip-dissolution model for crack propagation (28); the applied strain must exceed a threshold value to rupture the passive surface film in order for environmental effects to occur. (Note that this need not imply that the observed threshold strain is the actual film rupture strain. The film rupture occurs at the crack tip and is controlled by the crack tip strain. The threshold strain measured in smoothspecimen tests is a surrogate that in essence controls the crack tip strain, but no numerical equality between the two need be implied). If each portion of the loading cycle above the threshold strain is equally damaging, the decrease in fatigue life should follow line $A B C$ when slow rate is applied near peak tensile strain and line ADC when it is applied near peak compressive strain. The results are in agreement with this behavior, i.e., a slow strain rate applied during each portion of the loading cycle above the threshold strain is equally effective in decreasing fatigue life. Additional tests with 3/4-cycle or 7/8-cycle slow strain rates and on other heats of ferritic steels are in progress to validate these results. 
Table 5. Results of exploratory fatigue test in which a slow strain rate is applied only during a portion of the tensile-loading cycle

\begin{tabular}{|c|c|c|c|c|c|c|c|c|c|}
\hline Test Number & $\begin{array}{c}\text { Environ- } \\
\text { ment }\end{array}$ & $\begin{array}{c}\text { Dissolved } \\
\text { Oxygen (ppb) }\end{array}$ & $\begin{array}{c}\mathrm{pH} \\
\text { at } \mathrm{RT}\end{array}$ & $\begin{array}{l}\text { Conducti- } \\
\text { vity }(\mathrm{mS} / \mathrm{cm})\end{array}$ & $\begin{array}{l}\text { Wave- } \\
\text { form }^{\mathrm{a}}\end{array}$ & $\begin{array}{c}\text { Fraction of } \\
\text { strain at slow } \\
\text { rate } \\
\end{array}$ & $\begin{array}{l}\text { Stress } \\
\text { Range } \\
(\mathrm{MPa}) \\
\end{array}$ & $\begin{array}{c}\text { Strain } \\
\text { Range (\%) }\end{array}$ & $\begin{array}{c}\text { Life } \\
\mathrm{N}_{25} \\
\text { (Cycles) } \\
\end{array}$ \\
\hline \multicolumn{10}{|c|}{ Al06-Gr B carbon steel } \\
\hline 1667 & Air & - & - & - & $\mathrm{H}$ & 0.50 & 999.2 & 0.758 & 5,261 \\
\hline 1668 & Air & - & - & - & I & 0.25 & 998.5 & 0.758 & 5,139 \\
\hline 1695 & Air & - & - & - & G & 0.25 & 993.4 & 0.756 & 5,240 \\
\hline 1722 & Air & - & - & - & E & 0.25 & 955.8 & 0.758 & 4,087 \\
\hline 1734 & Air & - & - & - & $\mathrm{J}$ & 0.125 & 970.0 & 0.757 & 4,122 \\
\hline 1737 & Air & - & - & - & $\mathrm{F}$ & 0.125 & 963.7 & 0.757 & 4,105 \\
\hline 1677 & Hi DO & 800 & 6.0 & 0.11 & $\mathrm{H}$ & 0.666 & 926.5 & 0.762 & 545 \\
\hline 1678 & Hi DO & 700 & 5.9 & 0.14 & I & 0.347 & 944.4 & 0.780 & 615 \\
\hline 1703 & Hi DO & 650 & 5.9 & 0.13 & I & 0.347 & 942.4 & 0.760 & 553 \\
\hline 1698 & Hi DO & 600 & 6.1 & 0.08 & G & 0.319 & 909.1 & 0.756 & 1,306 \\
\hline 1692 & Hi DO & 700 & 6.0 & 0.10 & $\mathrm{I}^{\mathrm{b}}$ & 0.347 & 936.4 & 0.764 & 261 \\
\hline 1684 & Hi DO & 700 & 6.0 & 0.09 & D & 0.334 & 964.0 & 0.762 & 1,935 \\
\hline 1728 & Hi DO & 700 & 5.9 & 0.07 & E & 0.167 & 969.3 & 0.740 & 1,649 \\
\hline 1732 & Hi DO & 600 & 5.9 & 0.08 & $\mathrm{E}$ & 0.167 & 954.5 & 0.734 & 2,080 \\
\hline 1741 & Hi DO & 600 & 6.0 & 0.09 & $\mathrm{~J}$ & 0.170 & 896.8 & 0.785 & 888 \\
\hline 1742 & Hi DO & 520 & 6.0 & 0.09 & $\mathrm{~F}$ & 0.084 & 948.0 & 0.783 & 2,093 \\
\hline \multicolumn{10}{|c|}{ A533-Gr B low-alloy steel } \\
\hline$\overline{1708}$ & Air & - & - & - & $\mathrm{H}$ & 0.50 & 898.2 & 0.754 & 5,355 \\
\hline 1710 & Air & - & - & - & I & 0.25 & 885.6 & 0.753 & 3,630 \\
\hline 1713 & Hi DO & 670 & 5.9 & 0.07 & $\mathrm{H}$ & 0.666 & 890.8 & 0.761 & 426 \\
\hline 1714 & Hi DO & 570 & 5.9 & 0.08 & I & 0.347 & 886.1 & 0.748 & 578 \\
\hline
\end{tabular}

a The various waveforms are shown in Fig. 14.

${ }^{b}$ A slow strain rate of $0.0004 \% / s$ was used for this test.

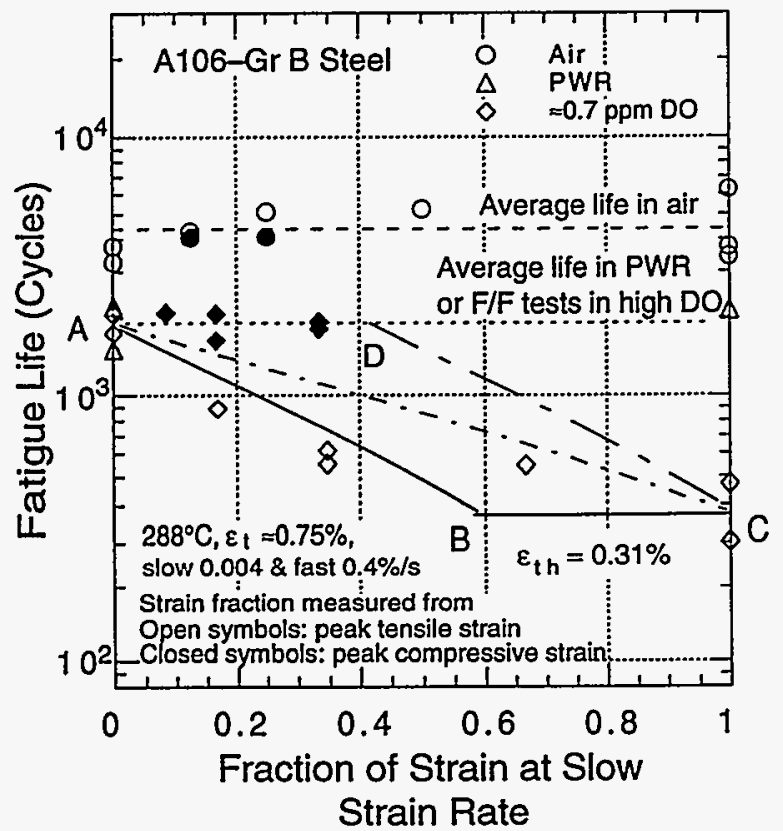

Figure 15. Fatigue life of A106-Gr B steel tested in air and water with loading waveforms where slow strain rate is applied during a fraction of the tensile cycle.

\section{CONCLUSIONS}

Fatigue behavior of A106-Gr B carbon steel and A533$\mathrm{Gr} B$ low-alloy steel has been investigated in air and water environments. The results confirm the significant reduction in fatigue life in high-DO water and strong dependence on strain rate. The results show that although the structure and cyclic-hardening behavior of carbon and low-alloy steels are distinctly different, there is little or no difference in susceptibility to environmental degradation of fatigue life of these steels, when sulfur levels are comparable. The A106-Gr B carbon steel exhibits pronounced dynamic strain-aging, whereas strain-aging effects are modest in the A533-Gr B low-alloy steel.

For both steels, the results indicate only a marginal effect of simulated PWR environment on fatigue life, e.g., fatigue life is lower by less than a factor of 2 than that in air. Furthermore, fatigue life is independent of strain rate; a three-order-of-magnitude decrease in strain rate does not cause an additional decrease in life.

Environmental effects on fatigue life are significant at high DO levels, e.g., $0.5-0.8 \mathrm{ppm}$ DO. For high-DO water, the effects of various loading and environmental parameters on fatigue life of carbon and low-alloy steels are summarized below. 
(i) The fatigue life of carbon and low-alloy steels decreases rapidly with decreasing strain rate. For both steels, the effect of strain rate saturates at $\approx 0.001 \% / \mathrm{s}$. Compared with tests in air, fatigue life of A106-Gr B steel in high-DO water is lower by factors of $2,4,10$, and 18 at strain rates of 0.4 , $0.04,0.004$, and $0.0004 \% / \mathrm{s}$, respectively. A further decrease in strain rate by one order of magnitude does not cause additional decrease in fatigue life.

(ii) A minimum strain is required for environmentally assisted decrease in fatigue life. For the loading conditions used in the present study, this threshold strain range appears to be $\approx 0.36 \%$ for the heats of carbon and low-alloy steels investigated.

(iii) A slow strain rate applied during the tensile-loading cycle is more effective in environmentally assisted reduction in fatigue life than when applied during the compressive-loading cycle. Also, a slow strain rate applied during both the compressive- and the tensile-loading cycles does not cause further decrease in fatigue life.

(iv) The results also indicate that a slow strain rate applied during each portion of the tensile-loading cycle above the threshold strain is equally effective in decreasing fatigue life.

(v) A hold period at peak tensile strain decreases fatigue life in high-DO water but not in air. A 5-min hold is sufficient to reduce fatigue life.

(vi) A detailed metallographic examination of the test specimens and exploratory tests indicate that the reduction in fatigue life in high-DO water is primarily due to environmental effects on fatigue crack propagation. Environment appears to have little or no effect on crack nucleation. Although all specimens tested in water show surface micropitting, there is no indication that these micropits enhance crack nucleation. Irrespective of environment, cracks in carbon and low-alloy steels nucleate either along slip bands, carbide particles, or at the ferrite/pearlite phase boundaries.

\section{ACKNOWLEDGMENTS}

The authors are grateful to W. F. Burke, T. M. Galvin, W. F. Michaud, W. K. Soppet, and D. Gavenda for their contributions to the experimental effort in this program. This work was supported by the Office of Nuclear Regulatory Research of the U.S. Nuclear Regulatory Commission, under FIN Number A2212; Program Manager: Dr. M. McNeil.

\section{REFERENCES}

1. "Criteria of Section III of the ASME Boiler and Pressure Vessel Code for Nuclear Vessels," The American Society of Mechanical Engineers, United Engineering Center, New York, Library of Congress Catalog No. 56-3934, 1989.
2. "Tentative Structural Design Basis for Reactor Pressure Vessels and Directly Associated Components (Pressurized, Water Cooled Systems)," PB 151987, U.S. Department of Commerce, Office of Technical Service, 1 Dec. 1958 Revision.

3. Hale, D. A., Wilson, S. A., Kiss, E., and Gianuzzi, A. J., "Low Cycle Fatigue Evaluation of Primary Piping Materials in a BWR Environment," GEAP-20244, U.S. Nuclear Regulatory Commission, Sept. 1977.

4. Hale, D. A., Wilson, S. A., Kass, J. N., and Kiss, E., "Low Cycle Fatigue Behavior of Commercial Piping Materials in a BWR Environment," J. Eng. Mater. Technol., Vol. 103, pp. 15-25, 1981.

5. Ranganath, S., Kass, J. N., and Heald, J. D., "Fatigue Behavior of Carbon Steel Components in High-Temperature Water Environments," in Low-Cycle Fatigue and Life Prediction, ASTM STP 770, C. Amzallag, B. N. Leis, and P. Rabbe, eds., American Society for Testing and Materials, Philadelphia, PA, pp. 436-459, 1982.

6. Terrell, J. B., "Fatigue Life Characterization of Smooth and Notched Piping Steel Specimens in $288^{\circ} \mathrm{C}$ Air Environments," NUREG/CR-5013, MEA-2232, May 1988.

7. Terrell, J. B., "Effect of Cyclic Frequency on the Fatigue Life of ASME SA-106-B Piping Steel in PWR Environments," J. Mater. Eng., Vol. 10, pp. 193-203, 1988.

8. Hicks, P. D., "Fatigue of Ferritic Steels," in Environmentally Assisted Cracking in Light Water Reactors: Semiannual Report October 1990_March 1991, NUREG/CR-4667 Vol. 12, ANL-91/24, pp. 3-18, Aug. 1991.

9. Hicks, P. D., and Shack, W. J., "Fatigue of Ferritic Steels," in Environmentally Assisted Cracking in Light Water Reactors, Semiannual Report, April-September 1991, NUREG/CR-4667 Vol. 13, ANL-92/6, pp. 3-8, March 1992.

10. Chopra, O. K., Michaud, W. F., and Shack, W. J., "Fatigue of Ferritic Steels," in Environmentally Assisted Cracking in Light Water Reactors, Semiannual Report, October 1992March 1993, NUREG/CR-4667 Vol. 16, ANL-93/27, pp. 3-19, Sept. 1993.

11. Higuchi, M., and Iida, K., "Fatigue Strength Correction Factors for Carbon and Low-Alloy Steels in OxygenContaining High-Temperature Water," Nucl. Eng. Des. 129, pp. 293-306, 1991.

12. K. Iida, H. Kobayashi, and M. Higuchi, Predictive Method of Low Cycle Fatigue Life of Carbon and Low Alloy Steels in High Temperature Water Environments, NUREG/CP-0067, MEA-2090, Vol. 2, April 1986. 
13. Nagata, N., Sato, S., and Katada, Y., "Low-Cycle Fatigue Behavior of Low-Alloy Steels in High-Temperature Pressurized Water," in Transactions of the 10th International Conf. on Structural Mechanics in Reactor Technology, F, A. H. Hadjian, ed., American Association for Structural Mechanics in Reactor Technology, Anaheim, CA, 1989.

14. Majumdar, S., Chopra, O. K., and Shack, W. J., "Interim Fatigue Design Curves for Carbon, Low-Alloy, and Austenitic Stainless Steels in LWR Environments," NUREG/CR-5999, ANL-93/3, April 1993.

15. Prater, T. A., and Coffin, L. F., "The Use of Notched Compact-Type Specimens for Crack Initiation Design Rules in High-Temperature Water Environments," in Corrosion Fatigue: Mechanics Metallurgy, Electrochemistry, and Engineering, ASTM STP 801, T. W. Crooker and B. N. Leis, eds., American Society for Testing and Materials, Philadelphia, pp. 423-444 1983.

16. Prater, T. A., and Coffin, L. F., "Notch Fatigue Crack Initiation in High Temperature Water Environments: Experiments and Life Prediction," J. of Pressure Vessel Technol., Trans. ASME, 109, pp. 124-134, 1987.

17. Speidel, M. O., and Magdowski, R. M., "Stress Corrosion Cracking of Nuclear Reactor Pressure Vessel Steel in Water: Crack Initiation versus Crack Growth," Corrosion 88, Paper No. 283, St. Louis, MO, March 1988.

18. Ford, F. P., and Andresen, P. L., "Stress Corrosion Cracking of Low-Alloy Pressure Vessel Steel in $288^{\circ} \mathrm{C}$ Water," in Proc. 3rd Int. Atomic Energy Agency Specialists' Meeting on Subcritical Crack Growth, NUREG/CP-0112, Vol. 1, pp. 37-56, Aug. 1990.

19. Scott, P. M., and Tice, D. R., "Stress Corrosion in LowAlloy Steels," Nucl. Eng. Des. 119, pp. 399-413, 1990.

20. Cullen, W. H., "The Effects of Sulfur Chemistry and Load Ratio on Fatigue Crack Growth Rates in LWR Environments," in Proc. of the 2nd Int. Atomic Energy Agency Specialists' Meeting on Subcritical Crack Growth, NUREG/CP-0067, MEA-2090, Vol. 2, pp. 339-355, April 1986.

21. Atkinson, J. D., Bulloch, J. H., and Forrest, J. E., "TA Fractographic Study of Fatigue Cracks Produced in A533B Pressure Vessel Steel Exposed to Simulated PWR Primary Water Environments," in Proc. of the 2nd Int. Atomic Energy Agency Specialists' Meeting on Subcritical Crack Growth, NUREG/CP-0067, MEA-2090, Vol. 2, pp. 269290, April 1986.

22. Van Der Sluys, W. A., and DeMiglio, D. S., "An Investigation of Fatigue Crack Growth in SA508-2 in a $288^{\circ} \mathrm{C}$ PWR Environment by a Constant $\Delta \mathrm{K}$-Test Method," in Proc. Int. Atomic Energy Agency Specialists' Meeting on Subcritical Crack Growth, NUREG/CP-0044, MEA-2014, Vol. 1, pp. 44-64, May 1983.

23. Bulloch, J. H., "A Review of the Fatigue Crack Extension Behavior of Ferritic Pressure Vessel Materials in Pressurized Water Reactor Environments," Res. Mechanica 26; pp. 95$172,1989$.

24. Kassner, T. F., Shack, W. J., Ruther, W. E., and Park, J. H., "Environmentally Assisted Cracking of Ferritic Steels," in Environmentally Assisted Cracking in Light Water Reactors: Semiannual Report, April-September 1990, NUREG/CR4667, Vol. 11, ANL-91/9, pp. 2-9, May 1991.

25. Macdonald, D. D., Smialowska, S., and Pednekar, S., The General and Localized Corrosion of Carbon and Low-Alloy Steels in Oxygenated High-Temperature Water, NP-2853, Feb. 1983.

26. Kuniya, J., Anzai, H., and Masaoka, I., "Effect of MnS Inclusions on Stress Corrosion Cracking in Low-Alloy Steels," Corrosion, Vol 48, No. 5, pp. 419-425, 1992.

27. Chopra, O. K., Michaud, W. F., and Shack, W. J., "Fatigue of Ferritic Steels," in Environmentally Assisted Cracking in Light Water Reactors, Semiannual Report, March 1993April 1994, NUREG/CR-4667 Vol. 17, ANL-94/16, pp. 122, June 1994.

28. Ford, F. P., Ranganath, S., and Weinstein, D., "Environmentally Assisted Fatigue Crack Initiation in LowAlloy Steels - A Review of the Literature and the ASME Code Design Requirements," EPRI Report TR-102765, Aug. 1993. 